
Digitized by the Internet Archive in 2011 with funding from

LYRASIS members and Sloan Foundation

http://www.archive.org/details/tobaccosubstatio1941ande 




\title{
Tobacco Substation at Windsor Report for 1940
}

\author{
P. J. ANDERSON
}

T. R. SWanback and S. B. LeCompte, Jr.

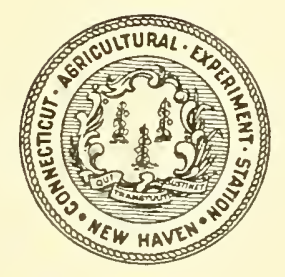

Tommerticut

Anrinultural Fixperment Station

A̛ru Haun 



\section{CONTENTS}

INTRODUCTION

Influence of Nitrogenous Fertilizer Materials on the

Nitrogen Content of Cured Leaves

Ammonification and Nitrification of Certain Fertilizer Materials.. 232

The Relative Efficiency of Nitrogen from Cottonseed Meal, Castor

Pomace and Soybean Oil Meal ............................................................. 238

Effect on Yield and Grading .......................................................... 241

Effect of Soybean Oil Meal on Shade Tobacco ................................. 243

Comparison of Cottonseed Meal with Soybean Oil Meal ................... 245

Residual Effect of Stable Manure on Yield and Grading of

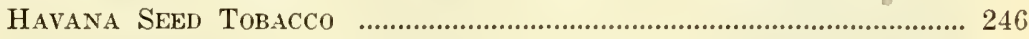

Further Experiments oN the Relation of Calcium to The

GROWTH OF TOBACCO ....................................................................... 249

Effect on Bur'n ................................................................................. 253

Chemical Analyses .......................................................................... 254

Discussion and Conclusions ............................................................... 259

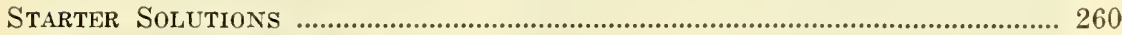

Commercial Starter Solutions .......................................................... 262

IRRIgATION OF HAVANA SEED TOBACCO IN 1940 .................................. 264

Tobacco Diseases iN 1940 ................................................................. 265

Downy Mildew (Blue Mold) .............................................................. 265

Bed Rots, Wildfire, Blackfire, Rootrots, Mosaic ................................ 268

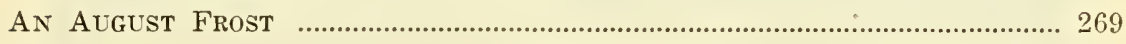

Lumarith, A Substitute for Glass in the Seedbed Sash .................. 269

STUDiES ON BLACK TOBACCO ......................................................................... 270

Chemical Examination of Plant Material ........................................ 271

Soil Tests in Relation to Black and Light Shade Tobacco ............... 276

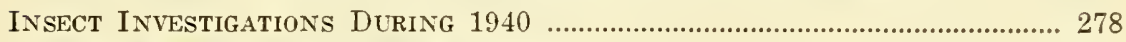

Flea Beetle and Thrips Expeximent ............................................... 278

Wireworm Control Experiments ............................................................ 281

Insect Abundance During 1940 ............................................................ 283

APPENDiX

Average Analyses of Materials Which May Be Used in Tobacco Fertilization 


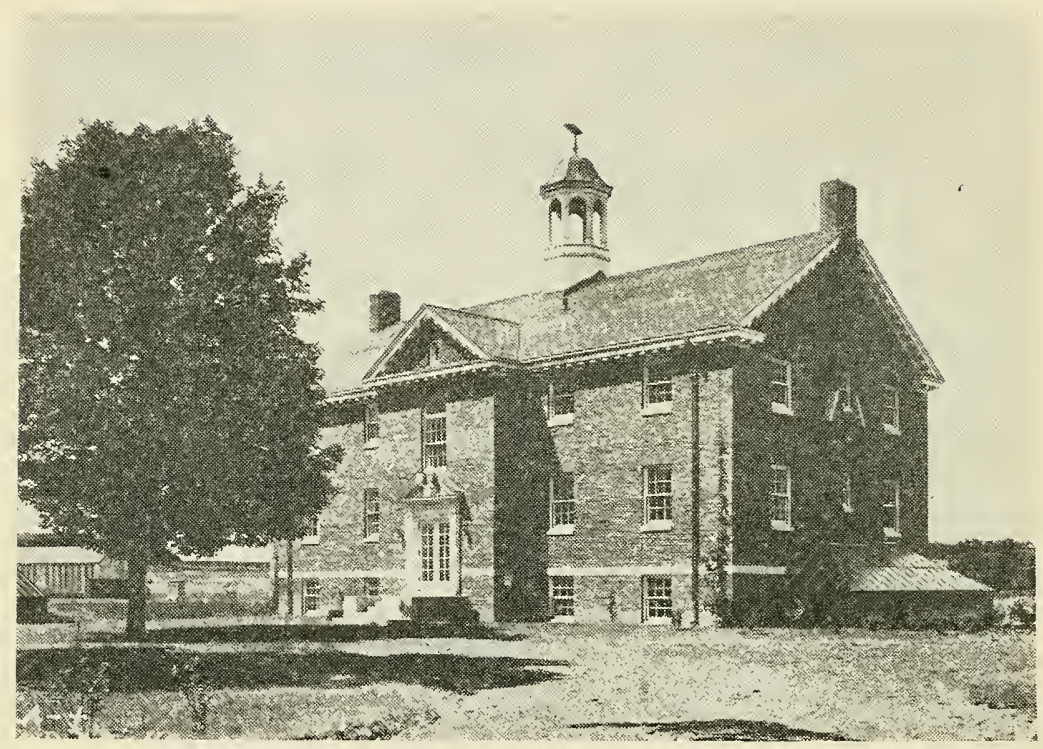

New Laboratory and Office Building of the Tobacco Substation at Windsor. 


\title{
TOBACCO SUBSTATION AT WINDSOR
}

\author{
Report for 1940
}

P. J. Anderson, T. R. Swanback And S. B. LeCompte, JR.

\section{$T^{\mathrm{T}}$} HE Nineteenth Annual Report of the Tobacco Substation at Windsor is presented herewith to acquaint growers and others interested in tobacco production in this State with the progress of the work and investigation under way at the Substation.

On the whole, the season of 1940 was not very favorable for tobacco in the Connecticut Valley. Both yield and quality of the crop were well below those of 1939, but much better than those of 1938. The explanation lies in the adverse distribution of rainfall during the growing season. At first rain was excessive. A fall of 4.55 inches between May 29 and June 1 was especially harmful in causing leaching of the fertilizer and packing of the soil. During the last week of July, however, the weather suddenly became too dry. Precipitation for August was less than half of normal so that crops, especially those on sandy fields, suffered from drought. The crop on the Station farm was somewhat below average, but not sufficiently poor to impair the results of our field tests since yields were comparative. The distribution of rainfall for the season is shown in Table 1.

\section{New Building for}

Tobacco Research modious and better equipped quarters will relieve the congestion caused by the expanding department and should greatly facilitate the work.

New Project on

Improvement of

It was stated in last year's report that a new building to house the activities of tobacco research was in process of construction. This was finally ready for occupancy on February 1, 1941. The comthe Connecticut Valley Shade Growers' Association which is providing a shade field suitable for trials and an experienced man for conducting the work. Field trials occupy a two-acre plot in the center of a shade tent in East Hartford. The Genetics Department of the Experiment Station at New Haven is also cooperating.

Twenty-five different strains of shade tobacco were grown in 1940 and the crop was good. The cured tobacco was sorted under the supervision of an expert on shade tobacco in charge of the standard grading service of the United States Department of Agriculture. 
Fermentation of

Tobacco

The study of the relation of yeasts to fermentation, the only project of the kind carried on by the Substation for some years, was discontinued when Dr. O. E. Street left the Station in 1939. In 1940 we began studying the chemical changes which occur during fermentation and the organisms associated with the process. This is another cooperative project in which laboratory work is conducted at the Tobacco Substation and warehouse investigations at Windsor Locks.

Placement of Fertilizers

Although it is the universal practice of tobacco growers in this State to broadcast all the fertilizer on the soil before the plants are set, the question is often raised whether or not it might be better to sow the material in, or close to, the rows, a practice that is current in many other tobacco sections. Row fertilization tried by growers and at the Substation has not improved the crop enough to warrant change. The Substation experiments were also abandoned because there was no proper machinery for reliable row application. A suitable machine has now been built and in 1940 an elaborate experiment was laid out and started on a two acre field. We hope that this will finally settle the problem for Connecticut.

Since the home mixing of tobacco fertilizers has

Information on Analyses of Ingredients
Tobacco Fertilizer

become a common practice with the growers, we receive numerous calls for tables of analyses of the ingredients to assist them in making up their formulas. The supply of pamphlets and bulletins in which we have previously published such tables has been exhausted and some new materials have come into use since their publication. In the appendix of this bulletin we therefore present a list of average analyses of materials which may be used for this purpose. The condensed table will be supplied in separate form on request.

In addition to its scientific functions, the Station is a service agency, furnishing information, but with no set program. The staff aids growers by analyzing soil samples, several thousands of which are submitted each year; by testing seed for germination, and by diagnosing diseases, identifying insects and prescribing controls for such pests.

Reports on field trials and experiments are made only when results have been tested under varying seasonal conditions and when some conclusions are justified. In the following pages are progress reports on a few of the Windsor projects. 
Table 1. Distribution of Rainfall in Inches at the Tobacco Substation, Windsor, 1940.

\begin{tabular}{|c|c|c|c|c|c|c|c|c|c|c|c|}
\hline & \multicolumn{2}{|l|}{ May } & \multicolumn{3}{|c|}{ June } & \multicolumn{3}{|c|}{ July } & \multicolumn{3}{|c|}{ August } \\
\hline \multicolumn{12}{|c|}{ BY IO-DAY PERIODS } \\
\hline 1.10 & $11-20$ & $21-31$ & $1-10$ & $11-20$ & $21-30$ & $1-10$ & $11-20$ & $2|-3|$ & 1.10 & $11-20$ & $2|-3|$ \\
\hline .88 & .65 & 2.55 & 3.21 & .68 & 1.99 & .97 & 1.92 & .83 & .21 & .81 & .54 \\
\hline \multicolumn{12}{|c|}{ BY MONTHS } \\
\hline & 4.08 & & & 5.88 & & & 3.72 & & & 1.56 & \\
\hline \multicolumn{12}{|c|}{ AVERAGE FOR PRECEDING 18 YEARS } \\
\hline & 3.34 & & & 3.76 & & & 3.63 & & & 4.35 & \\
\hline
\end{tabular}

\section{INFLUENCE OF THE NITROGENOUS FERTILIZER MATERIALS ON THE NITROGEN CONTENT OF THE CURED LEAVES}

Nitrogen is the first limiting food element of tobacco growing in Connecticut. It is the most costly element in the fertilizer and leaches most readily from the soil. Its reactions and transformations from the time it is deposited in the soil until it passes off in the smoke of the cigar are the most complex and least understood of any of the contributing elements. Nitrogen is offered to the farmer and the fertilizer mixer in a greater variety of materials than any other element. At the Experiment Station, more time and field space have been devoted to nitrogen fertilizer tests than to all other fertilizer trials.

The oldest nitrogen fertilizer experiment at the Station farm is a series of field plot tests on Field $\mathrm{V}$ where 12 different nitrogenous materials, each used as the only source of nitrogen, have been compared for the last 15 years. The last report on this experiment was published in 1935 (Bul. 386: 546-552). The comparative values of the different fertilizer materials have been measured in terms of yield and grading of the crop. The effects on the soil from continuous use of each material have also been studied, particularly with reference to the changes in reaction and the process of ammonification and nitrification and rates of leaching. Effects on combustion characteristics of the leaf have also been measured.

Previous to 1939, however, no analyses of the cured leaves were made for the purpose of comparing the effects of the various nitrogenous fertilizers on the chemical composition of leaves. Such analyses were started with the crop of 1939. Since all the other elements applied to the soil, except nitrogen, were the same for all plots, the most pronounced differences in chemical composition were anticipated in the forms and ratios of the nitrogen fractions. Fermented samples of the light and dark grades of the crop of 1939 were, there- 
fore, analyzed by the Analytical Chemistry Department of the Station to determine the percentages of total nitrogen, nitric nitrogen, ammonia nitrogen and nicotine. The results of these analyses are presented in Table 2.

The season of 1939 was dry; there was little leaching of the nitrogen and thus the crop as a whole was characteristic of a highnitrogen crop. Once during the season, July 26, these plots were irrigated and this may have caused some leaching of the nitrates on all the plots. The effect of such loss of nitrate was visible, however, only on a cottonseed meal plot which was on the upper tier of plots, and which showed paler leaves in the field and, at the time of sorting, many starved yellow leaves. Of the three cottonseed meal plots, this was by chance the one selected for analyses. This fact should be taken into consideration in the interpretation of the data presented in Table 2.

Total nitrogen. The tobacco showing the lowest total nitrogen was from the cottonseed meal plot. This merely demonstrates that, with an inadequate supply of nitrogen in the soil, the leaves will contain a smaller percentage of total nitrogen.

Reference to Table 5 shows that during the latter part of July the soil on this plot contained a lower supply of nitrate than any of the plots tested.

The second lowest in total nitrogen was tobacco from the soybean meal plot, and the highest percentage was in the tobacco from the sulfate of ammonia plot. This high nitrogen content where sulfate of ammonia is used may furnish a clue to the poor quality and burn of tobacco so fertilized.

Outside of the three materials just mentioned, the other seven gave practically the same percentages of nitrogen in the leaf, the differences being too small to be significant.

Nitric nitrogen. The cottonseed meal tobacco, being starved, as explained above, contained no trace of nitrate, indicating that every bit of obtainable nitrogen had been utilized in elaboration of the protein parts of the leaf cells. The lack of nitrate in the corn gluten meal tobacco is not easy to explain. The highest percentage of nitric nitrogen was in the nitrate of soda tobacco, as might be anticipated from the form in which it was applied to the soil and its fractional method of application. With the possible exception of sulfate of ammonia, the other materials resulted in only insignificant differences in nitrate content of the leaves.

Ammonic nitrogen. Next to cottonseed meal, the use of nitrate of soda gave the lowest percentage of ammonia in the leaves. The differences between the others seem too small to be significant. The dark grade from the corn gluten meal plot had the highest percentage of ammonia. 


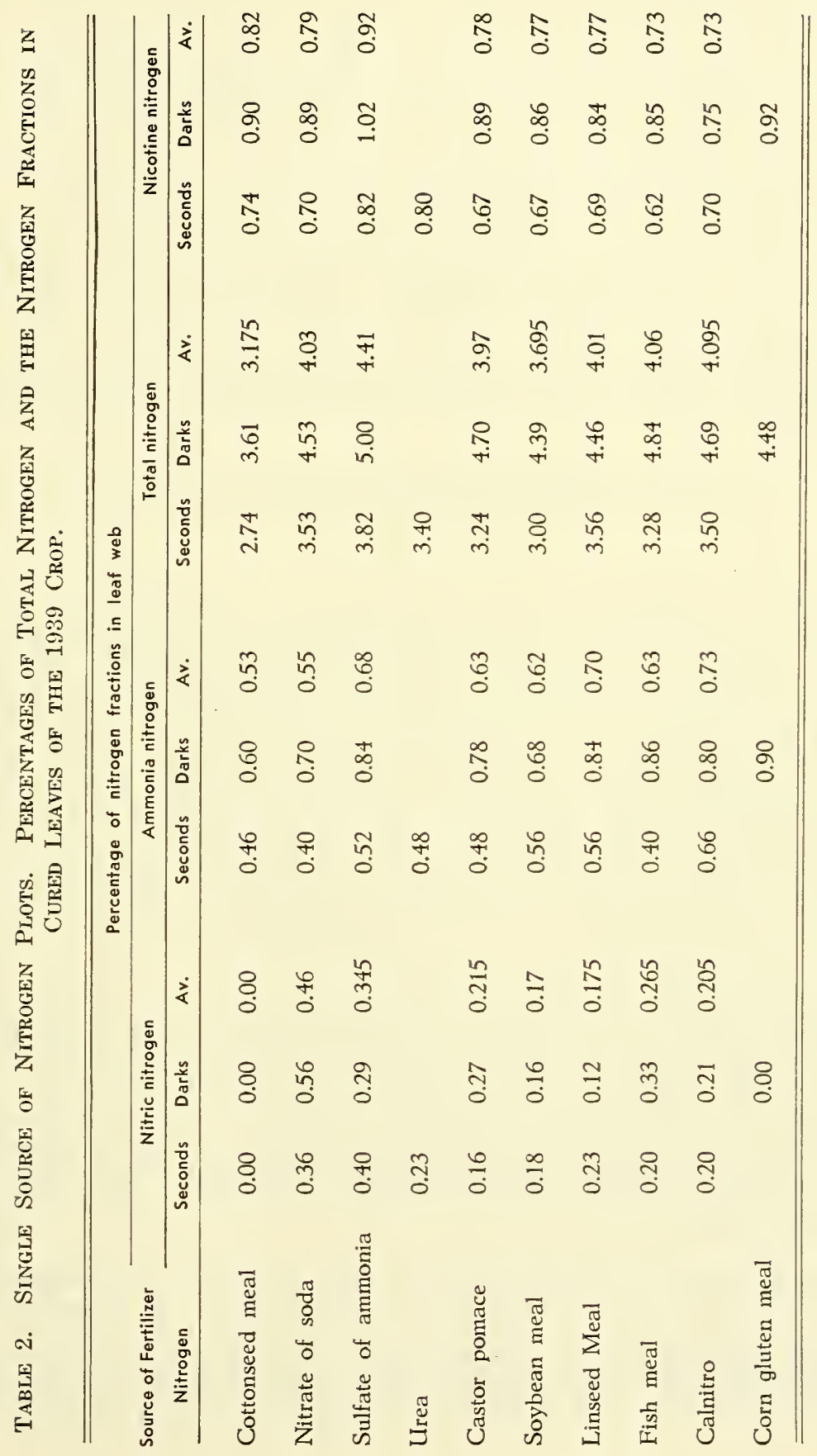


Nicotine. Sulfate of ammonia gave a considerably higher percentage of nicotine than any of the others and this may furnish another clue to the strong smoking quality of tobacco fertilized with this material. Castor pomace and cottonseed meal came next in order of nicotine percentage and the others ranged downward with only small differences between them. It is interesting to note that the starved cottonseed meal tobacco, although low in total nitrogen, nitrate and ammonia, still had as much nicotine as the others.

In every plot, the upper leaves (darks) had a higher percentage of total nitrogen, ammonia and nicotine than the lower leaves (seconds), conforming in this respect with many previous analyses which have been published in our annual reports (see particularly Sta. Bul. 433: 177-186). The percentage of nicotine in the crop as a whole is higher than we have usually found. The percentage of nitric nitrogen shows no relation to the position of the leaves on the stalk.

\section{AMMONIFICATION AND NITRIFICATION OF CERTAIN FERTILIZER MATERIALS}

\section{T. R. SWANBACK}

The availability of nitrogenous fertilizer materials has been studied over a number of years at this Station. The chief measurements have been the effect on yields and quality of tobacco. Moreover, the rate of nitrification was studied by Street ${ }^{1}$, since it is commonly known that nitrate nitrogen is the most suitable form for plant growth. Morgan and Street ${ }^{2}$, furthermore, have studied liberation of nitrates from various fertilizer materials by means of lysimeter data collected during several years. Thus the nitrate production by the various materials has been taken as a criterion or a method of evaluation of the different sources of nitrogen. The amount of nitrates in a soil fluctuates, depending on rate of formation, removal by plants and leaching rains, soil reaction in conjunction with lime supply, and temperature.

Nitrate measurements during the growing season do not give a complete picture of the supply of total available nitrogen in the soil. This is especially true where ammoniacal and organic materials are used. Since the proteins of organic materials first break down into ammonia compounds, these constitute a potential supply for nitrate production. Thus it is important to ascertain, within reasonable limits, the rate at which organic fertilizers ammonify. Such knowledge would be valuable in estimating the available nitrogen under a growing crop.

Ammonium ions behave in the soil somewhat like potassium ions, i. e., they become fixed, although not as firmly as phosphates,

${ }^{1}$ Conn. Agr. Expt. Sta. Bul. 386: 552-572.

${ }^{2}$ Morgan, M. F. and O. E. Street. Seasonal water and nitrate leachings in relation to soil and source of fertilizer nitrogen. Conn. Agr. Expt. Sta. Bul. 429: 33-38. 
and thus greatly resist leaching rains. A soil examined after a heavy rain may show little nitrate nitrogen but considerable ammonia.

The following investigation was undertaken in order to reveal the course of ammonia production and nitrate formation from various nitrogenous fertilizers under the tobacco crop.

For two seasons, 1939 and 1940, twelve of the plots (described under "nitrogenous fertilizers") were sampled before fertilizers were applied and at weekly intervals thereafter until the first week in August. Ammonia nitrogen and nitrates were determined. Ammonia was determined according to a modified Nessler method ${ }^{1}$, and nitrates, by the standard phenodisulphonic acid method.

The various plots on the field in question were fertilized on May 24 in 1939 and on May 27 in 1940. While the early summer of 1939 was quite dry, an excessive rainfall occurred in late May of 1940. (See introduction.) These two extremes of weather conditions greatly influenced the content of available nitrogen in the surface soil, as indicated in the report that follows.

Ammonia production. On the nitrate of soda plot, nitrate was applied at five different intervals. All the nitrogen was obviously in the nitrate form in the soil of this plot; the amounts of ammonia shown in Tables 3 and 4 originated from decayed cover crop and residues from previous tobacco crops. The sulfate of ammonia treatment in 1939 proved to have more ammonia in the soil during the early part of the season than was applied (200 pounds $\mathrm{N}$ per A.) indicating that ammonia, accumulated from this source, caused a delay in nitrification. The dry weather apparently prevented any appreciable amount from becoming nitrified. A salt incrustation on the surface of the soil of the sulfate of ammonia plot indicated capillary rise of soluble sulfates and their accumulation in concentrations unfavorable for nitrification. There was sufficient rainfall late in June to remedy such condition.

On the other hand, in 1940 less than half of the ammonia nitrogen applied as sulfate of ammonia was found in the surface soil about a week after application. In the meantime, 4.55 inches of rain had fallen, leaching much of the ammonia from this sandy soil into the coarse sand subsoil from which it could not return to the surface. This was indicated by a special sampling on July 1, when substantial amounts of ammonia nitrogen ( 7 pounds and 9 pounds per acre, respectively) were recovered at the 12-inch and 24-inch sampling depths. Morgan and Street ${ }^{1}$ have shown that much ammonia can be leached from very sandy soils before nitrification be-

${ }^{1}$ Twenty-five grams of moist soil (moisture determined) were transferred to 6-ounce bottles; $50 \mathrm{cc}$. of 1/80 $\mathrm{N}$ copper acetate solution were added. The mixtures were placed in a shaking machine and shaken for 30 minutes and then filtered. Ammonia was determined directly on the clear filtrate. A photelometer was used to compare the colors with known standards. (Nessler-Folin, Koch-McMeekin modification, was used because it gives a clear color instead of a colloidal suspension).

${ }^{1}$ Morgan and Street, Bul. 429: 29. 
comes effective. Urea showed a similar behavior, to a lesser degree, suggesting that the hydrolysis of urea to ammonia nitrogen had not been completed when the leaching occurred. Ammonia from the organic materials was developed to higher levels in 1940 than in 1939, indicating no apparent leaching of ammonium per se.

Table 3. Ammonia Nitrogen Content in Solls, May-July, 1939. FIELD V.

\begin{tabular}{|c|c|c|c|c|c|c|c|c|c|c|c|c|}
\hline \multirow{3}{*}{ Source of nitrogen } & \multirow{3}{*}{$\begin{array}{l}\text { Repli- } \\
\text { ca- } \\
\text { tions }\end{array}$} & \multicolumn{11}{|c|}{ Pounds ammonia nitrogen per acre } \\
\hline & & \multicolumn{2}{|c|}{ May } & \multicolumn{4}{|c|}{ June } & \multicolumn{5}{|c|}{ July } \\
\hline & & 22 & 29 & 5 & 12 & 19 & 26 & 3 & 10 & 17 & 24 & 31 \\
\hline itrate of soda & & 2 & 44 & 9 & 20 & 9 & 18 & 25 & 24 & 5 & 8 & 8 \\
\hline Sulfa & & 3 & $260+$ & $260+$ & $260+$ & $260+$ & $260+$ & 150 & 42 & 46 & 35 & 62 \\
\hline Urea & & 2 & $260+$ & 250 & $260+$ & 66 & 74 & 80 & 32 & 10 & 12 & 6 \\
\hline Cottonseed meal & 1 & 3 & 157 & 147 & 135 & 24 & 44 & 11 & 34 & 6 & 9 & 8 \\
\hline “ & 2 & 2 & 164 & 120 & 114 & 54 & 35 & 25 & 30 & 7 & 7 & 6 \\
\hline Soybean oil meal & 1 & 2 & 118 & 94 & 150 & 42 & 32 & 25 & 25 & 7 & 7 & 8 \\
\hline " “ & 2 & 3 & 132 & 150 & 106 & 55 & 38 & 35 & 30 & 7 & 7 & 9 \\
\hline $\begin{array}{lll} & \end{array}$ & 3 & 2 & 138 & 115 & 126 & 32 & 40 & 16 & 21 & 5 & 8 & 5 \\
\hline Castor pomace & 1 & $\overline{2}$ & 141 & 124 & 114 & 56 & 42 & 38 & 30 & 7 & 14 & 6 \\
\hline " & 2 & 2 & 91 & 108 & 130 & 76 & 58 & 72 & 40 & 12 & 24 & 7 \\
\hline Linsee & & 2 & 136 & 167 & 150 & 32 & 67 & 34 & 28 & 6 & 9 & 7 \\
\hline Dry ground fish & & 2 & 173 & 166 & 150 & 48 & 32 & 34 & 25 & 6 & 22 & 6 \\
\hline
\end{tabular}

Table 4. Ammonia Nitrogen Content in Soils, June-July, 1940. FIELD V.

\begin{tabular}{|c|c|c|c|c|c|c|c|c|}
\hline \multirow{3}{*}{ Source of nitrogen } & \multirow{3}{*}{$\begin{array}{l}\text { Repli- } \\
\text { cations }\end{array}$} & \multicolumn{7}{|c|}{ Pounds ammonia nitrogen per acre } \\
\hline & & \multicolumn{4}{|c|}{ June } & \multicolumn{3}{|c|}{ July } \\
\hline & & 3 & 11 & 17 & 24 & 1 & 8 & 15 \\
\hline $\begin{array}{l}\text { Nitrate of soda } \\
\text { Sulfate of ammonia } \\
\text { Urea } \\
\text { Cottonseed meal } \\
\text { Soybean oil meal } \\
\text { Castor pomace } \\
\text { Linseed meal } \\
\text { Dry ground fish }\end{array}$ & $\begin{array}{l}\ddot{.} \\
\ddot{1} \\
1 \\
2 \\
1 \\
2 \\
1 \\
2 \\
1 \\
2 \\
. .\end{array}$ & $\begin{array}{r}8 \\
95 \\
124 \\
158 \\
149 \\
242 \\
180 \\
174 \\
180 \\
189 \\
215 \\
148\end{array}$ & $\begin{array}{r}9 \\
106 \\
80 \\
80 \\
86 \\
262 \\
246 \\
114 \\
113 \\
230 \\
146 \\
196\end{array}$ & $\begin{array}{r}20 \\
104 \\
50 \\
118 \\
50 \\
142 \\
90 \\
78 \\
130 \\
88 \\
62 \\
64\end{array}$ & $\begin{array}{l}20 \\
57 \\
38 \\
58 \\
25 \\
80 \\
66 \\
64 \\
42 \\
54 \\
55 \\
40\end{array}$ & $\begin{array}{l}14 \\
33 \\
36 \\
73 \\
28 \\
60 \\
60 \\
55 \\
45 \\
46 \\
32 \\
46\end{array}$ & $\begin{array}{l}10 \\
19 \\
15 \\
18 \\
16 \\
18 \\
20 \\
25 \\
20 \\
22 \\
16 \\
22\end{array}$ & $\begin{array}{l}\operatorname{trace} \\
1 \\
2 \\
2 \\
2 \\
3 \\
5 \\
4 \\
4 \\
5 \\
4 \\
7\end{array}$ \\
\hline
\end{tabular}

Nitrate production. As a whole, the content of nitrates was. higher in 1940 than in 1939, as seen in Tables 5 and 6 . This, no doubt, was due to more favorable moisture conditions in the soil, especially in the early part of the season, a point that will be discussed further in relation to the ammonia-nitrate ratios. From nitrate of soda all of the nitrogen, except a small amount of ammonia from 
residual sources, was revealed as nitrates. Urea transformed into nitrates so rapidly that the nitrate levels were almost equal to those of the nitrate of soda plots. Sulfate of ammonia produced the lowest level of nitrates. Among the organic sources, soybean oil meal seemed to produce a higher nitrate level than any of the others for the two years.

Materials supplying nitrogen in ammonia or ammonifiable form may be expected to show relatively more ammonia than nitrate nitrogen during the early stages of their nitrogen transformation. As nitrification proceeds, the ammonia is utilized by the oganisms involved in the process. Thus the ratio of nitrate nitrogen to ammonia nitrogen is an expression of the pace of nitrification during the season. Table 7 shows the average $\mathrm{NO}_{3}-\mathrm{N}: \mathrm{NH}_{4}-\mathrm{N}$ ratios for corresponding dates during the two years of the experiment. These data are also plotted graphically in Figure 1.

Nitrate of soda, while indicating the expected high ratio of nitrates to ammonia, shows a dip at midseason caused by depletion of nitrates by crop removal or leaching, or both, previous to the addition of further increments of the material. Urea, rapidly converted to ammonia, begins to form nitrates rapidly, attaining nitrate levels approaching those produced by the accumulated nitrates from successive nitrate of soda applications. However, the ammonia persists for some time, giving an average nitrate-ammonia ratio somewhat lower than with the organic materials, which liberate their ammonia more nearly in pace with nitrate production.

Table 5. Nitrate Nitrogen Content in Solls, May-July, 1939.

Field V.

\begin{tabular}{|c|c|c|c|c|c|c|c|c|c|c|c|c|}
\hline \multirow{3}{*}{ Source of nitrogen } & \multirow{3}{*}{$\begin{array}{l}\text { Repli- } \\
\text { cations }\end{array}$} & \multicolumn{11}{|c|}{ Pounds nitrate nitrogen per acre } \\
\hline & & \multicolumn{2}{|c|}{ May } & \multicolumn{4}{|c|}{ June } & \multicolumn{5}{|c|}{ July } \\
\hline & & 22 & 29 & 5 & 12 & 19 & 26 & 3 & 10 & 17 & 24 & 31 \\
\hline $\begin{array}{l}\text { Nitrate of soda } \\
\text { Sulfate of ammonia } \\
\text { Urea } \\
\text { Cottonseed meal } \\
\text { Soybean oil meal } \\
\text {." “ ". } \\
\text { Castor pomace } \\
\text { Linseed meal } \\
\text { Dry ground fish }\end{array}$ & $\begin{array}{l}\ddot{.} \\
\ddot{0} \\
\ddot{1} \\
2 \\
1 \\
2 \\
3 \\
1 \\
2 \\
. . \\
. .\end{array}$ & $\begin{array}{l}2 \\
3 \\
3 \\
3 \\
3 \\
3 \\
3 \\
3 \\
3 \\
3+ \\
3+ \\
3\end{array}$ & $\begin{array}{r}70 \\
6 \\
7 \\
7 \\
7 \\
6 \\
6 \\
6 \\
6 \\
5 \\
8 \\
7\end{array}$ & $\begin{array}{l}61 \\
16 \\
28 \\
38 \\
29 \\
43 \\
47 \\
53 \\
43 \\
27 \\
38 \\
42\end{array}$ & $\begin{array}{l}79 \\
23 \\
57 \\
50 \\
59 \\
81 \\
40 \\
60 \\
32 \\
18 \\
44 \\
52\end{array}$ & $\begin{array}{l}74 \\
29 \\
34 \\
35 \\
26 \\
62 \\
38 \\
58 \\
37 \\
33 \\
48 \\
38\end{array}$ & $\begin{array}{l}64 \\
38 \\
64 \\
49 \\
63 \\
96 \\
71 \\
52 \\
56 \\
55 \\
89 \\
70\end{array}$ & $\begin{array}{l}83 \\
40 \\
80 \\
92 \\
58 \\
34 \\
29 \\
42 \\
60 \\
56 \\
66 \\
50\end{array}$ & $\begin{array}{l}68 \\
33 \\
68 \\
23 \\
32 \\
97 \\
12 \\
43 \\
59 \\
51 \\
38 \\
45\end{array}$ & $\begin{array}{l}62 \\
60 \\
66 \\
23 \\
73 \\
74 \\
47 \\
8 \\
84 \\
64 \\
64 \\
67\end{array}$ & $\begin{array}{l}52 \\
36 \\
34 \\
10 \\
12 \\
16 \\
30 \\
24 \\
58 \\
28 \\
12 \\
44\end{array}$ & $\begin{array}{r}16 \\
25 \\
38 \\
4 \\
5 \\
6 \\
5 \\
4 \\
28 \\
12 \\
22 \\
22\end{array}$ \\
\hline
\end{tabular}




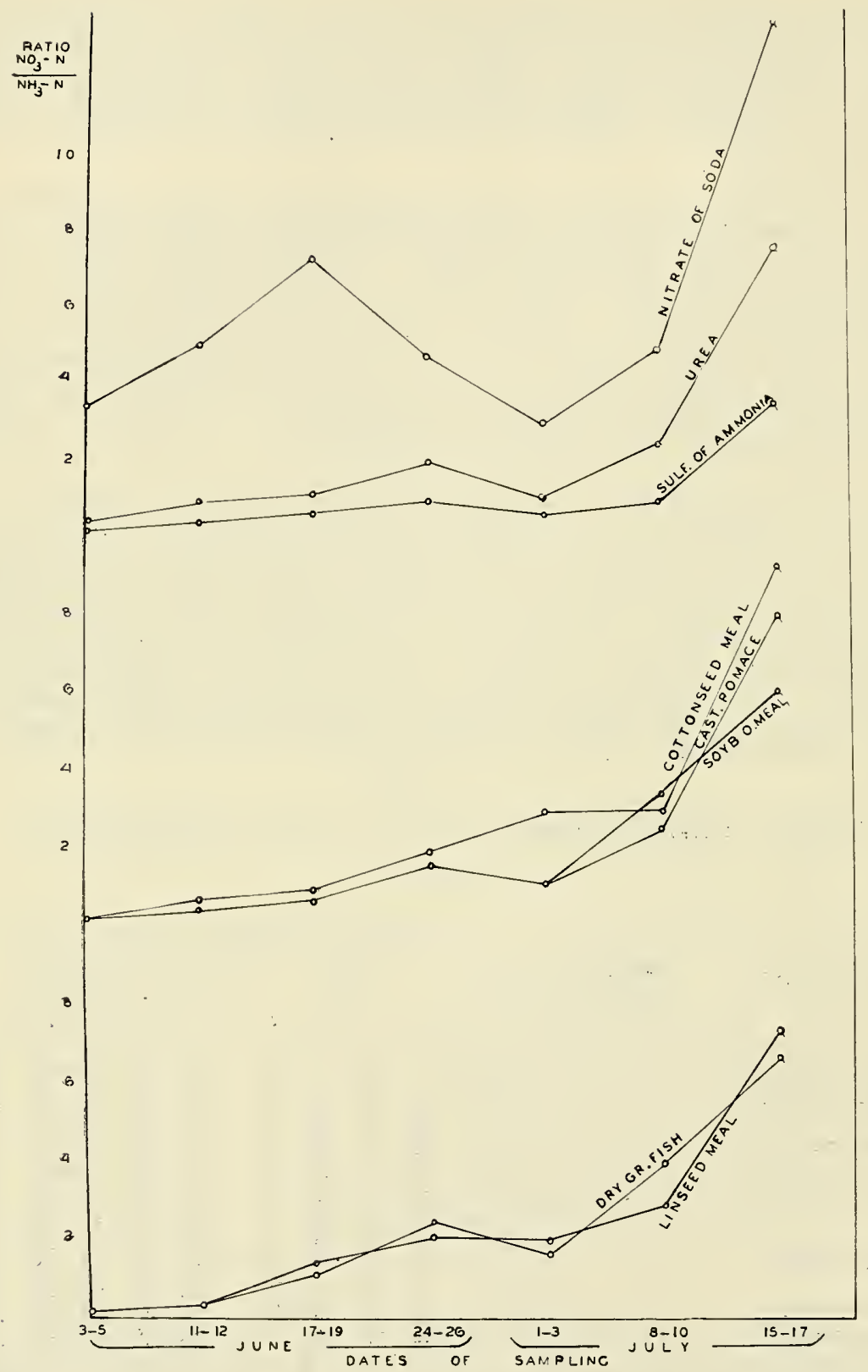

FIGURE 1. Rates of nitrification (average of two years) of some fertilizer materials in comparison with nitrate of soda. 
Table 6. Nitrate Nitrogen Content in Solls, June-August, 1940. FIELD V.

\begin{tabular}{|c|c|c|c|c|c|c|c|c|c|c|c|}
\hline \multirow{3}{*}{ Source of nitrogen } & \multirow{3}{*}{$\begin{array}{l}\text { Repli- } \\
\text { cations }\end{array}$} & \multicolumn{10}{|c|}{ Pounds nitrate nitrogen per acre } \\
\hline & & \multicolumn{4}{|c|}{ June } & \multicolumn{5}{|c|}{ July } & \multirow{2}{*}{$\frac{\text { Aug. }}{5}$} \\
\hline & & 3 & 11 & 17 & 24 & 1 & 8 & 15 & 22 & 29 & \\
\hline $\begin{array}{l}\text { Nitrate of soda } \\
\text { Sulfate of ammonia } \\
\text { Urea } \\
\text { Cottonseed meal } \\
\text { Soybean oil meal } \\
\text { Castor pomace } \\
\text { Linseed meal } \\
\text { Dry ground fish }\end{array}$ & $\begin{array}{l}\ddot{.} \\
\ddot{0} \\
\ddot{1} \\
2 \\
1 \\
2 \\
1 \\
2 \\
1 \\
2\end{array}$ & $\begin{array}{r}4 \\
8 \\
13 \\
8 \\
16 \\
19 \\
13 \\
16 \\
17 \\
7 \\
12 \\
7\end{array}$ & $\begin{array}{r}58 \\
70 \\
96 \\
70 \\
96 \\
142 \\
85 \\
62 \\
64 \\
110 \\
95 \\
46\end{array}$ & $\begin{array}{r}129 \\
95 \\
78 \\
95 \\
120 \\
174 \\
111 \\
108 \\
110 \\
100 \\
122 \\
81\end{array}$ & $\begin{array}{r}116 \\
98 \\
120 \\
106 \\
104 \\
223 \\
130 \\
190 \\
87 \\
138 \\
172 \\
94\end{array}$ & $\begin{array}{r}36 \\
29 \\
52 \\
90 \\
70 \\
126 \\
40 \\
90 \\
36 \\
82 \\
94 \\
72\end{array}$ & $\begin{array}{r}68 \\
16 \\
44 \\
89 \\
73 \\
102 \\
86 \\
108 \\
58 \\
118 \\
54 \\
136\end{array}$ & $\begin{array}{r}7 \\
5 \\
19 \\
13 \\
34 \\
16 \\
26 \\
28 \\
43 \\
32 \\
8 \\
15\end{array}$ & $\begin{array}{r}24 \\
1 \\
7 \\
9 \\
18 \\
11 \\
30 \\
24 \\
6 \\
25 \\
9 \\
11\end{array}$ & $\begin{array}{r}24 \\
2 \\
3 \\
8 \\
5 \\
17 \\
17 \\
18 \\
3 \\
10 \\
3 \\
15\end{array}$ & $\begin{array}{r}8 \\
4 \\
3 \\
3 \\
11 \\
1 \\
4 \\
30 \\
5 \\
22 \\
1 \\
18\end{array}$ \\
\hline
\end{tabular}

Table 7. Ratio of Nitrate Nitrogen to Ammonia Nitrogen. Average For Two Seasons (1939-1940) on Comparative Dates, and

Average For SEASONS. Field $\mathrm{V}$.

Average ratios $\mathrm{NO}_{3}-\mathrm{N} / \mathrm{NH}_{3}-\mathrm{N}$

\begin{tabular}{|c|c|c|c|c|c|c|c|c|c|c|}
\hline \multirow{2}{*}{ Source of nitrogen } & \multicolumn{4}{|c|}{ June } & \multicolumn{3}{|c|}{ July } & \multicolumn{2}{|c|}{ Average for } & \multirow{2}{*}{$\frac{\text { Average for }}{\text { both years }}$} \\
\hline & 3.5 & $11-12$ & 17.19 & $24-26$ & $1-3$ & $8-10$ & $15-17$ & 1939 & 1940 & \\
\hline Nitrate of soda & 3.6 & 5.1 & 7.4 & 4.7 & 2.9 & 4.6 & 13.7 & 5.8 & 6.1 & 5.95 \\
\hline Sulfate of ammonia & .7 & .4 & .5 & .9 & .6 & .8 & 3.5 & .4 & 1.5 & .95 \\
\hline Urea & .1 & .9 & 1.1 & 2.0 & 1.2 & 2.5 & 7.4 & 1.6 & 2.2 & 1.90 \\
\hline Cottonseed meal & .2 & .7 & 1.0 & 2.0 & 2.9 & 2.9 & 9.3 & 1.7 & 3.7 & 2.70 \\
\hline Soybean oil meal & .3 & .6 & 1.2 & 2.2 & 1.4 & 3.5 & 6.0 & 2.0 & 2.3 & 2.25 \\
\hline Castor pomace & .2 & .4 & .8 & 1.9 & 1.2 & 2.6 & 8.2 & 1.7 & 2.6 & 2.15 \\
\hline Linseed meal & .1 & .4 & 1.5 & 2.0 & 2.0 & 3.0 & 7.4 & 2.5 & 2.3 & 2.40 \\
\hline Dry ground fish & .2 & 3 & 1.0 & 2.3 & 1.6 & 4.0 & 6.6 & 2.6 & 2.0 & 2.30 \\
\hline
\end{tabular}

Sulfate of ammonia, supplying all of its nitrogen as ammonia in the initial application, seems to exert some delaying effect on the rate of nitrification since it is slowest of all the materials in producing increase in its nitrate-ammonia ratio.

Among the organic materials, cottonseed meal provides nitrates at the highest relative proportion in relation to ammonia during most of the season, resulting in the practical disappearance of ammonia by the July 15 to 17 sampling dates. Lower ratios at the later periods, especially in case of soybean meal, indicate either that the nitrification of the material proceeds less rapidly, or that the ammonification of some portion of the organic nitrogen is in progress at a later period. The rate of disappearance of ammonia nitrogen in relation to nitrate nitrogen is apparently of the order: cottonseed meal, linseed meal, dry ground fish, soybean oil meal, and castor pomace, based on the averages of the two years. However, there are marked 
irregularities at the various sampling periods and in the separate years.

From this it is inferred that a safe practice is to include several nitrogen sources in the fertilizer formula, in order to provide the most uniform ratio of nitrates to ammonia, and to provide adequate, but not excessive, quantities of nitrates in the later growth period when the needs are greatest. This is perhaps more important for shade grown tobacco than for stalk-cut types.

Table 7 also indicates a generally higher ratio of nitrates to ammonia during the 1940 season than in 1939. Better moisture conditions in the latter year promoted a more rapid conversion of ammonia to nitrates. The sulfate of ammonia plot lost much of its ammonia by early leaching in 1940, as previously indicated; hence the nitrification of its remaining ammonia was less retarded. For some reason nitrates resulting from fish and linseed meal were relatively higher in relation to ammonia during the drier 1939 season. Soybean oil meal was not consistently different in the two years. Thus, with the irregular distribution of rainfall and consequent variation in soil moisture conditions prevalent in the Connecticut Valley, several sources of nitrogen for the tobacco crop may be expected to have further advantage over a single source.

\section{The Relative Efficiency of Nitrogen from Cottonseed Meal,}

\section{Castor Pomace and Soybean Oil Meal}

Often it has been said that castor pomace produces dark tobacco. T'his might have been more true several years ago when this material was of a much coarser grind than that offered on the market today. Obviously a coarser material decays more slowly in the soil, thus producing available nitrogen at a relatively slow rate which may delay ripening of the crop. Castor pomace of the fine grind used at present has been found to nitrify as easily as any other organic, as shown in the above studies.

In our work with castor pomace we have found that this material on an equal nitrogen basis produces higher yields and a generally higher level of nitrates in the soil than cottonseed meal, while no dark cast of the tobacco has been observed. This might be due to the fact that the plots at the Station are located on light, sandy loam, a warm soil, but it is readily seen that darker tobacco might be produced on heavier (and colder) soils with such apparent greater efficiency of castor pomace.

What is said about castor pomace, seems also to apply in a measure to the more recently introduced soybean oil meal.

The graphs of Figure 2 illustrate the variation in nitrate levels in soils for two years from the three sources of nitrogen: cottonseed meal, castor pomace and soybean oil meal. It is seen that most of the time soybean oil meal reaches higher levels than cottonseed meal, while castor pomace shows the higher level at the latter part 
of the season. In both years frequent heavy showers occurred during the last few days of June, causing a sudden drop of nitrates from the surface soil. During the latter part of July, rapid crop removal caused a steady downward trend of soil nitrates.

If, for further comparison, the average levels for the season were to be considered, they are, for cottonseed meal, 42 pounds of nitrate nitrogen per acre; for castor pomace 46, and for soybean oil meal 53 pounds.

Since these facts show that there is definite difference in the efficiency of the nitrogen in these materials, it was thought that a definite ratio might be established by experiments. In other words, less nitrogen per acre either in castor pomace or in soybean oil meal should produce about the same results as the larger amount of nitrogen in cottonseed meal.

A series of plots was laid out on a field (Pomeroy) containing a somewhat heavier soil than that on which the single sources of nitrogen had been investigated. Three one-fortieth-acre plots for each of the three sources of nitrogen were laid out in a randomized arrangement, with six rows per plot, half of which were harvested for records.

Tentatively, nitrogen from castor pomace was applied at the rate of 160 pounds per acre and soybean oil meal at the rate of 170 pounds. These two rates were compared with 200 pounds nitrogen derived from cottonseed meal. Employment of these rates, finally, was based on the indication that castor pomace held out too well at the end of the season and soybean oil meal built up unnecessarily high early levels of nitrates at the beginning, both in comparison with cottonseed meal (compare curves in Figure 2). The exact analyses for nitrogen of the three materials were 6.51 percent for cottonseed meal, 5.74 percent for castor pomace and 7.94 percent for soybean oil meal.

Phosphorus, potassium, calcium and magnesium were equalized for all plots. The fertilizer was applied on May 27, 1940, and Havana Seed was planted on June 5. During June, July and the first week in August, the soil on all the plots was sampled and nitrate and ammonia nitrogen were determined. The results are discussed below.

Ammonia developed quite rapidly from the three materials, as seen in Table 8 . If the average accumulation for the first three weeks of triplicate treatments is taken as a basis of comparison of the three sources, the level for cottonseed meal would be 116 pounds ammonia nitrogen per acre, for castor pomace 112, and for soybean oil meal 157 pounds. From this it would seem that soybean oil meal developed ammonia faster than the other two materials. Corresponding figures from previous investigations calculated from Tables 4 and 5 would be 130,125 and 153, respectively, whereas again soybean oil is ahead of the other two. On a percentage basis, cottonseed 
meal accumulates about 4 percent more ammonia than castor pomace and soybean oil meal about 31 percent more than castor pomace in the same period of time.

Nitrates, according to Table 9, reached the highest levels on the castor pomace plots, followed by soybean oil meal and cotton seed meal in the order mentioned. This is further elucidated in the graphs of Figure 3.

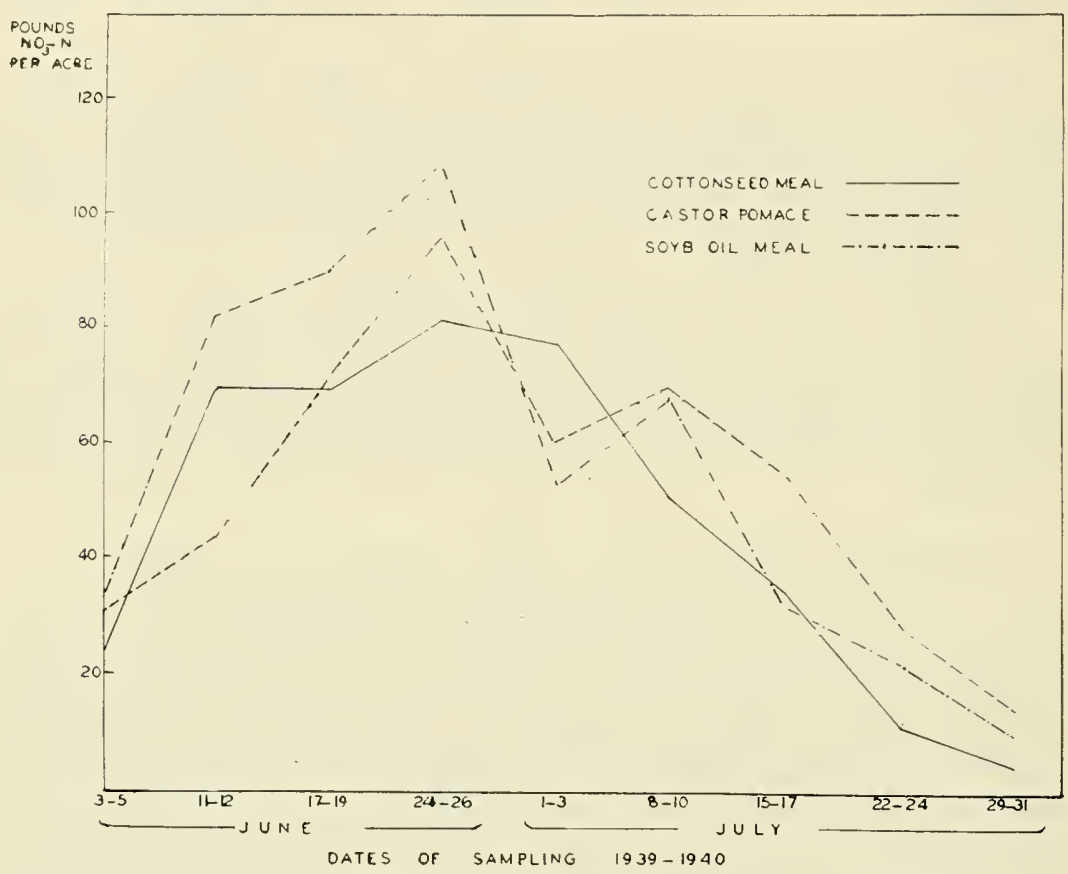

Figure 2. Nitrate levels in soils (two year's' average) produced by cottonseed meal, castor pomace and soybean oil meal.

Table 8. Ammonia Nitrogen Content in Solls, June-July, 1940. POMEROY Field.

\begin{tabular}{|c|c|c|c|c|c|c|c|c|}
\hline \multirow{3}{*}{ Source of nitrogen } & \multirow{3}{*}{$\begin{array}{l}\text { Repli- } \\
\text { cations }\end{array}$} & \multicolumn{7}{|c|}{ Pounds ammonia per acre } \\
\hline & & \multicolumn{4}{|c|}{ June } & \multicolumn{3}{|c|}{ July } \\
\hline & & 3 & 11 & 17 & 24 & 1 & 8 & 15 \\
\hline 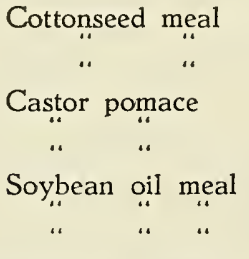 & $\begin{array}{l}1 \\
2 \\
3 \\
1 \\
2 \\
3 \\
1 \\
2 \\
3\end{array}$ & $\begin{array}{r}140 \\
108 \\
172 \\
132 \\
149 \\
95 \\
160 \\
188 \\
217\end{array}$ & $\begin{array}{r}150 \\
131 \\
155 \\
76 \\
185 \\
142 \\
157 \\
174 \\
192\end{array}$ & $\begin{array}{r}66 \\
88 \\
42 \\
83 \\
84 \\
66 \\
122 \\
87 \\
115\end{array}$ & $\begin{array}{l}42 \\
68 \\
59 \\
54 \\
48 \\
32 \\
48 \\
33 \\
51\end{array}$ & $\begin{array}{l}31 \\
62 \\
20 \\
30 \\
40 \\
24 \\
22 \\
26 \\
31\end{array}$ & $\begin{array}{l}7 \\
6 \\
6 \\
6 \\
8 \\
5 \\
9 \\
5 \\
8\end{array}$ & $\begin{array}{r}8 \\
7 \\
8 \\
8 \\
8 \\
7 \\
9 \\
10 \\
9\end{array}$ \\
\hline
\end{tabular}


Table 9. Nitrate Nitrogen Content in Solls, June-August, 1940. Polleroy Field.

\begin{tabular}{|c|c|c|c|c|c|c|c|c|c|c|c|}
\hline \multirow{3}{*}{ Source of nitrogen } & \multirow{3}{*}{$\begin{array}{l}\text { Repli- } \\
\text { cations }\end{array}$} & \multicolumn{10}{|c|}{ Pounds nitrate per acre } \\
\hline & & \multicolumn{4}{|c|}{ June } & \multicolumn{5}{|c|}{ July } & \multirow{2}{*}{$\frac{\text { Aug. }}{5}$} \\
\hline & & 3 & 11 & 17 & 24 & 1 & 8 & 15 & 22 & 29 & \\
\hline $\begin{array}{c}\text { Cottonseed meal } \\
\text { ". } \\
\text { Castor pomace } \\
\text { ". } \\
\text { Soybean oil meal } \\
\text { ". } \\
\text { ". }\end{array}$ & $\begin{array}{l}1 \\
2 \\
3 \\
1 \\
2 \\
3 \\
1 \\
2 \\
3\end{array}$ & $\begin{array}{l}25 \\
19 \\
43 \\
34 \\
29 \\
31 \\
27 \\
39 \\
27\end{array}$ & $\begin{array}{l}70 \\
64 \\
68 \\
86 \\
53 \\
48 \\
80 \\
93 \\
98\end{array}$ & $\begin{array}{r}104 \\
143 \\
153 \\
233 \\
176 \\
129 \\
136 \\
188 \\
84\end{array}$ & $\begin{array}{l}167 \\
152 \\
168 \\
226 \\
234 \\
222 \\
206 \\
187 \\
165\end{array}$ & 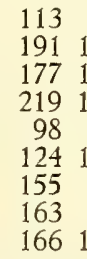 & $\begin{array}{r}90 \\
110 \\
131 \\
106 \\
54 \\
118 \\
82 \\
84 \\
177\end{array}$ & $\begin{array}{l}45 \\
47 \\
47 \\
99 \\
61 \\
25 \\
25 \\
26 \\
19\end{array}$ & $\begin{array}{r}11 \\
13 \\
38 \\
17 \\
9 \\
67 \\
44 \\
20 \\
13\end{array}$ & $\begin{array}{l}70 \\
55 \\
19 \\
89 \\
19 \\
52 \\
83 \\
31 \\
78\end{array}$ & $\begin{array}{r}4 \\
8 \\
23 \\
14 \\
5 \\
28 \\
32 \\
39 \\
26\end{array}$ \\
\hline
\end{tabular}

At the bottom of the same figure are shown the curves representing the nitrate-ammonia ratios. Up to the end of June, castor pomace accumulated nitrates at the most rapid pace, followed by soybean oil meal and cottonseed meal. In the following two weeks the differences were slight, while at the end of the season castor pomace was still leading. Moreover, it is seen that while the highest nitrate levels were attained in the last week of June, the ratio of nitrate to ammonia continued to increase up to the second week of July.

\section{Effect on Yield and Grading}

The growth of tobacco was quite uniform; no differences due to treatments could be observed in the field. The crop was harvested on August 17 and was properly cured and sorted. At the time the tobacco was examined on the sorting bench, the comments on quality of leaf grown from the three sources of nitrogen were as follows:

Cottonseed meal - fair to good texture, somewhat short, occasionally some prominent veins and starved leaves.

Castor pomace - good color and texture, no prominent veins, very few starved leaves.

Soybean oil meal good to very good color, size and texture; no starved leaves.

The evaluations were made previous to the calculations found in Table 10. It is of interest to note that they coincide remarkably well with the data presented therein.

It should be recalled that in this experiment the attempt was made to produce similar results from the three sources of nitrogen employed in different amounts. Thus a "ceiling" was expected at the outset of the experiment, based on previous results.

In first considering the yield data, it is seen that the average 


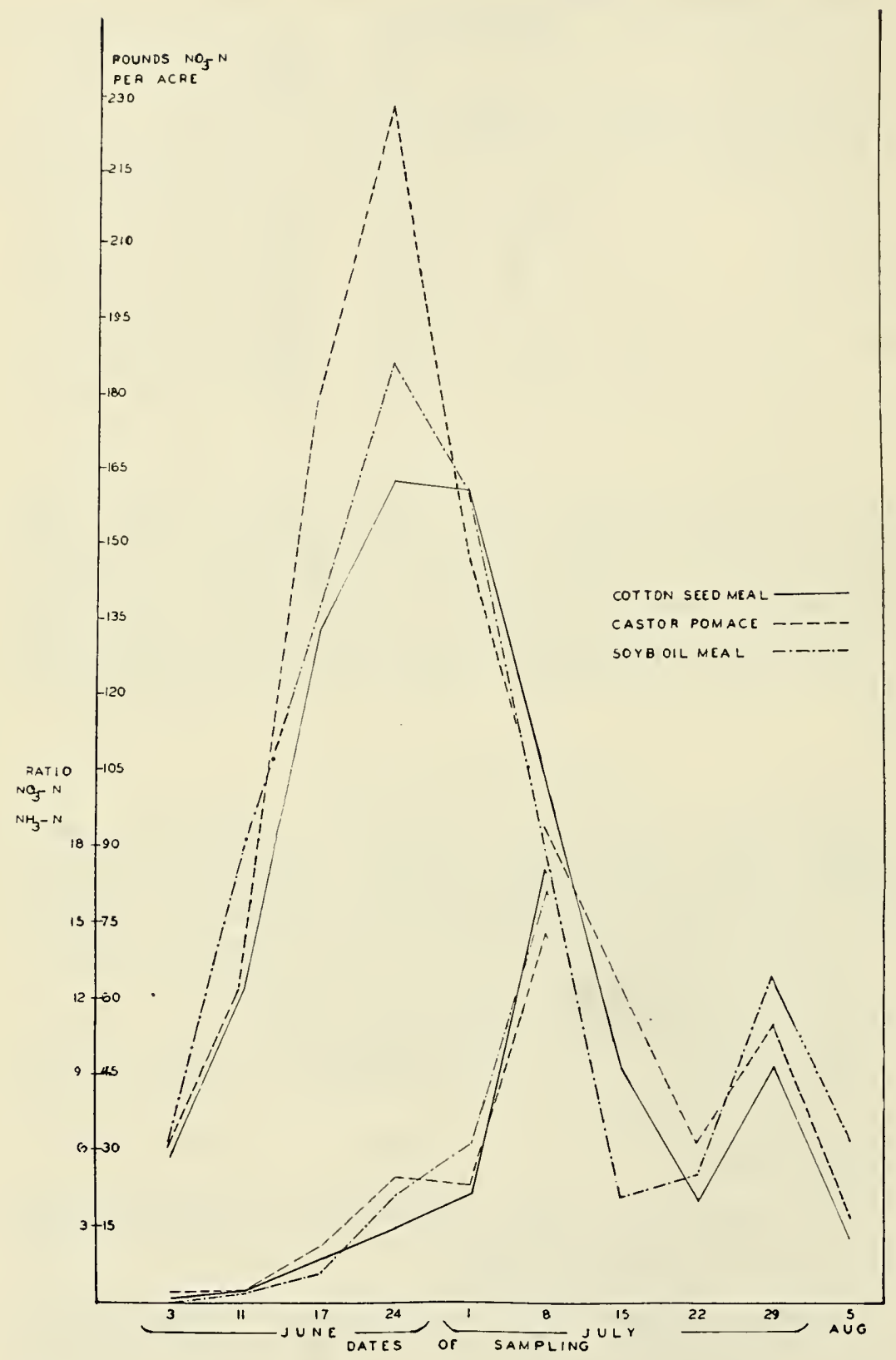

Frgure 3. Nitrate levels (upper curves) and rate of nitrification (lower) during 1940, produced by cottonseed meal, castor pomace and soybean oil meal. 
per acre produced by 200 pounds nitrogen from cottonseed meal is very nearly the same as that produced by 170 pounds nitrogen per acre from soybean oil meal. The actual difference is 3.4 percent in favor of cottonseed meal which, however, hardly is significant.

On the other hand, it is of greatest interest to note that castor pomace, with the rate of nitrogen reduced to 160 pounds per acre, still produced the highest average yield.

The grading is almost identical in the three treatments, with the exception that more "lights" and "mediums" were produced from the soybean product, resulting in a slightly higher grade index than for the other two materials.

With yield and grading taken into account, the relative crop values (cottonseed meal $=100$ ) for castor pomace and soybean oil meal would be 106.0 and 99.7 , respectively.

The results suggest that nitrogen derived from castor pomace is 20 to 25 percent more efficient than nitrogen in cottonseed meal. Nitrogen in soybean oil meal may be considered 14 to 15 percent more efficient than that in the old standby, cottonseed meal.

Table 10. Yield and Grading Records of Organic Nitrogen Plots. Pomeroy Field. Crop of 1940.

\begin{tabular}{|c|c|c|c|c|c|c|c|c|c|c|c|c|}
\hline \multirow[t]{2}{*}{$\begin{array}{l}\text { Source and pounds } \\
\text { of nitrogen per acre }\end{array}$} & \multicolumn{2}{|c|}{ Yield per A } & \multicolumn{8}{|c|}{ Percentage of grades } & \multicolumn{2}{|c|}{ Grade index } \\
\hline & Plot & Av. & $\mathrm{L}$ & $M$ & LS & SS & LD & DS & F & B & Plot & Av. \\
\hline 200 Cottonseed meal & $\begin{array}{l}1610 \\
1620 \\
1729\end{array}$ & 1653 & $\begin{array}{l}- \\
\overline{1}\end{array}$ & $\begin{array}{l}\overline{1} \\
1\end{array}$ & $\begin{array}{l}39 \\
32 \\
32\end{array}$ & $\begin{array}{l}9 \\
8 \\
8\end{array}$ & $\begin{array}{l}33 \\
39 \\
42\end{array}$ & $\begin{array}{r}9 \\
10 \\
4\end{array}$ & $\begin{array}{l}6 \\
6 \\
8\end{array}$ & $\begin{array}{l}4 \\
4 \\
4\end{array}$ & $\begin{array}{l}.388 \\
.369 \\
.378\end{array}$ & .378 \\
\hline 160 Castor pomace & $\begin{array}{l}1813 \\
1657 \\
1776\end{array}$ & 1749 & $\begin{array}{l}\overline{2} \\
-\end{array}$ & $\begin{array}{l}- \\
-\end{array}$ & $\begin{array}{l}37 \\
33 \\
29\end{array}$ & $\begin{array}{r}8 \\
10 \\
9\end{array}$ & $\begin{array}{l}40 \\
35 \\
40\end{array}$ & $\begin{array}{r}8 \\
8 \\
11\end{array}$ & $\begin{array}{l}6 \\
6 \\
6\end{array}$ & $\begin{array}{l}1 \\
3 \\
5\end{array}$ & $\begin{array}{l}.389 \\
.396 \\
.354\end{array}$ & .380 \\
\hline 170 Soybean oil meal & $\begin{array}{l}1613 \\
1598 \\
1582\end{array}$ & 1598 & $\begin{array}{l}\frac{1}{2} \\
2\end{array}$ & $\begin{array}{l}3 \\
3 \\
4\end{array}$ & $\begin{array}{l}32 \\
34 \\
30\end{array}$ & $\begin{array}{l}11 \\
11 \\
11\end{array}$ & $\begin{array}{l}33 \\
37 \\
38\end{array}$ & $\begin{array}{r}13 \\
9 \\
9\end{array}$ & $\begin{array}{l}5 \\
5 \\
5\end{array}$ & $\begin{array}{l}2 \\
1 \\
1\end{array}$ & $\begin{array}{l}.385 \\
.390 \\
.395\end{array}$ & .390 \\
\hline
\end{tabular}

From this it is evident that cottonseed meal is the least harmful material when used in excess or in a dry season when available nitrogen tends to accumulate heavily in the surface soil.

\section{Effect of Soybean Oil Meal on Shade Tobacco}

In order to extend the observations on the effect of soybean oil meal to shade tobacco, an experiment was made in cooperation with Mr. Tudor Holcomb on his plantation in West Granby.

With the exception of a few bents, a field was fertilized according to the grower's own fertilizer formula containing cottonseed meal as the principal nitrogen carrier. The remaining soil was treated 
with fertilizer in which soybean oil meal was substituted for cotton seed meal on the basis that it would be about 20 percent more efficient than the cottonseed material. Therefore, the part of the field receiving cottonseed meal had 40 pounds more nitrogen per acre than the rest of the field. Data, taken on three primings, are recorded in Table 11.

From these results there is further evidence that yields may be maintained and grading improved when soybean oil meal is used on an "efficiency basis".

For the grower who prefers to compose his own fertilizer formula, it would be most convenient to assign a correspondingly increased percentage to the nitrogen in soybean oil meal and castor pomace. For instance, if soybean oil meal has a guaranteed analysis of 7 percent nitrogen, it could be made to read at least 8 percent; castor pomace, with a guaranteed analysis of 5.0 percent, might be read at 6.25 percent or more.

Table 11. Yield and Grading Records in a Comparison Between Cottonseed Meal and Soybean Oil Meal on Shade Tobacco. Crop of 1940.

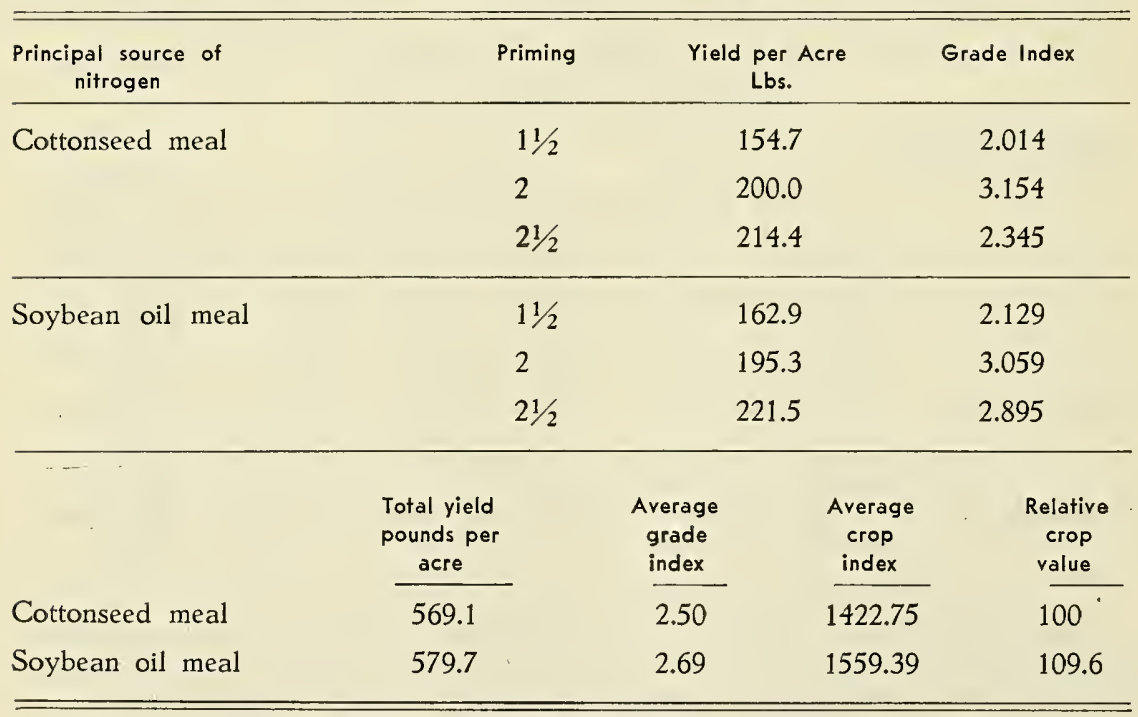

It is true that the experiments on efficiency of organic nitrogen cover only one year's results. On the other hand, several years' tests on single sources of nitrogen have indirectly led to the conclusions expressed above. 


\section{COMPARISON OF COTTONSEED MEAL WITH SOYBEAN OIL MEAL}

Field Tests of 1940

Since Field I was turned over to vegetable trials in 1940 , this test was transferred to Field IV which had grown a good uniform crop of tobacco the previous year. There were eight plots, each one-twenty-eighth of an acre, with six rows of Havana Seed tobacco in each. This allowed four replications of each treatment. The fer tilizer mixtures were the same as in previous years. Four plots had the nitrogen from cottonseed meal and the other four from soybean oil meal, all other ingredients being the same for both.

The plants were set on June 17. Growth was good and uniform during the season except for a low corner plot (N66 4) where the soil was too wet. This plot was discarded later on account of poor growth. The tobacco was harvested on September 4 and cured and sorted in the usual way.

The yield and sorting records are presented in Table 12. These data show an increase of 7 percent in the average yield and 8 percent in the average grade index in favor of the soybean plots. The increase in total crop value is 13.7 percent.

Since the tests have now been continued for five years, the results of the entire series are shown in Table 13. The average yield for the soybean plots during these years is 7 percent larger than for the cottonseed meal plots. The grade index is better by 6.5 percent on the soybean plots. The total crop index (yield $\times$ grade index) is 14 percent better.

Table 12. Comparison of Soybean Onl Meal with Cottoneeed Meal. Yield ANd Grading Records. Crop of 1940.

\begin{tabular}{|c|c|c|c|c|c|c|c|c|c|c|c|c|c|}
\hline \multirow{2}{*}{ Source of nitrogen } & \multirow{2}{*}{$\begin{array}{l}\text { Plot } \\
\text { No. }\end{array}$} & \multicolumn{2}{|c|}{$\begin{array}{l}\text { Yield } \\
\text { Lbs. per A. }\end{array}$} & \multicolumn{7}{|c|}{ Percentage of grades } & \multicolumn{2}{|c|}{$\begin{array}{l}\text { Grade } \\
\text { index }\end{array}$} & \multirow{2}{*}{$\begin{array}{c}\text { Av. } \\
\text { crop } \\
\text { index }\end{array}$} \\
\hline & & Plot & Av. & $\mathrm{L}$ & $\mathbf{M}|\mathrm{LS}|$ & SS & LD & DS & $F$ & B & Plot & Av. & \\
\hline Cottonseed meal & $\begin{array}{l}\text { N11-3 } \\
\text { N11-4 } \\
\text { N11-5 } \\
\text { N11-6 }\end{array}$ & $\begin{array}{l}2002 \\
1967 \\
2031 \\
2109\end{array}$ & 2027 & $\begin{array}{l}2 \\
8 \\
3 \\
8\end{array}$ & $\begin{array}{ll}1 & 35 \\
4 & 38 \\
1 & 34 \\
5 & 33 \\
\end{array}$ & $\begin{array}{l}1 \\
4 \\
4 \\
4\end{array}$ & $\begin{array}{l}32 \\
33 \\
41 \\
37\end{array}$ & $\begin{array}{l}5 \\
1 \\
1 \\
1\end{array}$ & $\begin{array}{l}\text { C } \\
7 \\
9 \\
7\end{array}$ & $\begin{array}{r}14 \\
5 \\
7 \\
5\end{array}$ & $\begin{array}{l}.371 \\
.457 \\
.393 \\
.445\end{array}$ & .417 & 848.26 \\
\hline Soybean oil meal & $\begin{array}{l}\text { N66-2 } \\
\text { N66-3 } \\
\text { N66-5 } \\
\text { N66-4 }\end{array}$ & $\begin{array}{l}2142 \\
2319 \\
2043\end{array}$ & 2168 & $\begin{array}{l}13 \\
12 \\
\end{array}$ & $\begin{array}{rr}4 & 35 \\
4 & 37 \\
- & 30\end{array} \mid$ & $\begin{array}{c}3 \\
3 \\
5 \\
\text { rve }\end{array}$ & $\begin{array}{l}34 \\
36 \\
48\end{array} \mid$ & $\begin{array}{l}\overline{1} \\
1 \\
d\end{array}$ & $\begin{array}{r}E \\
5 \\
11\end{array}$ & $\begin{array}{l}5 \\
2 \\
5\end{array}$ & $\begin{array}{l}.486 \\
.492 \\
.357\end{array}$ & .445 & 964.76 \\
\hline
\end{tabular}


Table 13. Comparison of Soybean Oil Meal with Cottonseed Meal. SumMary of Five Years' Trials.

\begin{tabular}{|c|c|c|c|c|c|c|c|c|c|c|c|c|c|}
\hline \multirow{2}{*}{$\begin{array}{l}\text { Plot } \\
\text { No. }\end{array}$} & \multirow{2}{*}{$\begin{array}{l}\text { Source of } \\
\text { nitrogen }\end{array}$} & \multicolumn{6}{|c|}{ Acre yield } & \multicolumn{6}{|c|}{ Grade index } \\
\hline & & 1936 & 1937 & 1938 & 1939 & 1940 & $A v .^{2}$ & 1936 & 1937 & 1938 & 1939 & 1940 & $\overline{A v t^{t}}$ \\
\hline $\begin{array}{l}\text { N11-3 } \\
\text { N11-4 } \\
\text { N11-5 } \\
\text { N11-6 }\end{array}$ & $\begin{array}{c}\text { Cottonseed } \\
\text { meal }\end{array}$ & $\begin{array}{l}2250 \\
2283 \\
2298\end{array}$ & $\begin{array}{l}1969 \\
1645 \\
1787\end{array}$ & $\begin{array}{r}1029 \\
900 \\
1010\end{array}$ & $\begin{array}{l}2163 \\
2036 \\
2097\end{array}$ & $\begin{array}{l}2002 \\
1967 \\
2031 \\
2109\end{array}$ & 1780 & $\begin{array}{l}.372 \\
.364 \\
.382\end{array}$ & $\begin{array}{l}.360 \\
.304 \\
.319\end{array}$ & $\begin{array}{l}.246 \\
.220 \\
.276\end{array}$ & $\begin{array}{l}.393 \\
.388 \\
.390\end{array}$ & $\begin{array}{l}.371 \\
.457 \\
.393 \\
.445\end{array}$ & .349 \\
\hline $\begin{array}{l}\text { N66-1 } \\
\text { N66-2 } \\
\text { N66-3 }\end{array}$ & $\begin{array}{l}\text { Soybean oil } \\
\text { meal }\end{array}$ & $\begin{array}{l}2113 \\
2218 \\
2169\end{array}$ & $\begin{array}{l}1972 \\
2022 \\
1888\end{array}$ & $\mid \begin{array}{l}1023 \\
1026 \\
1031\end{array}$ & $\begin{array}{l}2188 \\
2250 \\
2157\end{array}$ & $\begin{array}{l}2142 \\
2319 \\
2043\end{array}$ & 1904 & $\begin{array}{l}.389 \\
.376 \\
.421\end{array}$ & $\begin{array}{l}3.61 \\
.349 \\
.368\end{array}$ & $\begin{array}{l}.256 \\
.294 \\
.300\end{array}$ & $\begin{array}{l}.375 \\
.376 \\
.378\end{array}$ & $\begin{array}{l}.486 \\
.492 \\
.357\end{array}$ & .372 \\
\hline
\end{tabular}

${ }^{1}$ Average does not include N11-6

\section{RESIDUAL EFFECT OF STABLE MANURE ON YIELD AND GRADING OF HAVANA SEED TOBACCO}

Growers often have observed the improvement in tobacco grown on land that has been regularly manured over a series of years, either annually or at intervals of two or three years. There are some farms where this practice has been followed for a long time with good results although tobacco was planted year after year on the same field. On other farms the continuous use of manure has resulted in reduced yields, due to black rootrot, a disease that is favored by liberal use of stable manure. Such fields must be taken out of tobacco production and planted to other crops for several years before they will again yield a profitable crop of tobacco. Apparently, continuous application of manure can be practiced on some types of soil but not on others. Also the season makes a difference, the effects being more pronounced in certain years. Moreover, if rootrot resistant strains of tobacco are used, the injurious effects may be overcome.

A five-year experiment on continuous use of stable manure on plots at the Experiment Station farm (summarized in Conn. Sta. Bul. 326, pp. 384-387) showed an improvement during the first three years, followed by rapid decline until black rootrot made the tobacco worthless in the fifth year.

In another six-year experiment on shade tobacco in West Granby, where smaller amounts of manure were used and the commercial fertilizer was reduced by half, the results were favorable and, during the later years of the experiment, the tobacco was superior to that in adjacent plots where only commercial fertilizer was used. This indicated a growing residual beneficial influence. Although stable manure has been used longer than any other fertilizer in growing tobacco in Connecticut, there are still many unsolved problems in using it to best advantage.

An excellent opportunity to measure the residual effect of continuous manuring was afforded in the season of 1940 when Havana 
Seed tobacco was grown for the first time on a two-acre field that had been used for vegetable experiments for the preceding 10 years. In these vegetable trials, two strips of land extending across the field had received 40 loads of manure per acre every year. The tobacco rows in 1940 were planted in the opposite direction so that they crossed both of the manure strips at right angles. No manure was applied this year but the entire field, including the manure strips, was treated with a liberal application of an 8-4 8 commercial mixture.

Early in the growing season the tobacco on the manure strips began to outgrow plants on other parts of the field and the difference became more pronounced as the season advanced. At time of harvest, the manured plants were distinguished by their height, larger leaves and general leafy growth. Each strip was divided into two plots because the two sides of the field were planted on different dates. One hundred to one hundred and fifty plants were harvested from each manured plot, and a similar number from the four adjacent plots which received only commercial fertilizer.

The tobacco was harvested August 20 and sorted commercially in December.

The yield and sorting records are shown in Table 14.

According to these data, the previous use of manure increased the yield by 25 percent; and the grade index by 33 percent. In terms of crop index (calculated by multiplying the yield by grade index) the increase in value was 66 percent.

Table 14. Residual Effects of Stable Manure. Yield and Grading RECORDS OF CROP OF 1940.

\begin{tabular}{|c|c|c|c|c|c|c|c|c|c|c|c|c|c|}
\hline \multirow{2}{*}{ Treatment } & \multirow{2}{*}{ Plot No. } & \multirow{2}{*}{\multicolumn{2}{|c|}{$\begin{array}{l}\text { Yield } \\
\text { Lbs. per A. } \\
\text { Plot Av. }\end{array}$}} & \multicolumn{7}{|c|}{ Percentage of grades } & \multicolumn{2}{|c|}{$\begin{array}{l}\text { Grade } \\
\text { index }\end{array}$} & \multirow{2}{*}{$\begin{array}{l}\text { Crop } \\
\text { index }\end{array}$} \\
\hline & & & & $\mathrm{L}$ & $\mathrm{M}$ & LS & SS & $\angle D D^{D}$ & $\overline{S S|F|}$ & $\mathrm{B}$ & Plot & Av. & \\
\hline Stable manure & $\begin{array}{l}\text { M1 } \\
\text { M2 } \\
\text { M3 } \\
\text { M4 }\end{array}$ & $\begin{array}{l}1875 \\
1969 \\
1958 \\
1938\end{array}$ & 1935 & $\begin{array}{r}9 \\
18 \\
5 \\
15\end{array}$ & $\frac{\overline{5}}{5}$ & $\begin{array}{l}33 \\
31 \\
39 \\
33\end{array}$ & $\begin{array}{l}1 \\
6 \\
3 \\
3\end{array}$ & \begin{tabular}{l|l}
26 & 1 \\
23 & \\
28 & \\
26 &
\end{tabular} & \begin{tabular}{r|r|}
11 & 10 \\
9 & 6 \\
7 & 10 \\
4 & 9
\end{tabular} & $\begin{array}{r}10 \\
2 \\
8 \\
5\end{array}$ & $\begin{array}{l}.411 \\
.509 \\
.409 \\
.487\end{array}$ & .454 & 878.49 \\
\hline $\begin{array}{l}\text { Commercial } \\
\text { fertilizer }\end{array}$ & $\begin{array}{l}\text { M1 ch } \\
\text { M2 ch } \\
\text { M3 ch } \\
\text { M4 ch }\end{array}$ & $\begin{array}{l}1565 \\
1538 \\
1522 \\
1565\end{array}$ & 15.18 & $\begin{array}{l}7 \\
1 \\
\frac{3}{3}\end{array}$ & $\begin{array}{l}1 \\
- \\
\overline{1}\end{array}$ & & $\begin{array}{l}8 \\
7 \\
6 \\
3\end{array}$ & \begin{tabular}{l|l}
28 & 1 \\
21 & 2 \\
27 & 4 \\
27 & 1
\end{tabular} & \begin{tabular}{l|l|}
14 & 10 \\
22 & 14 \\
41 & 23 \\
13 & 15
\end{tabular} & $\begin{array}{l}2 \\
8 \\
4 \\
8\end{array}$ & $\begin{array}{l}.409 \\
.322 \\
.283 \\
.355\end{array}$ & .341 & 527.87 \\
\hline
\end{tabular}

Since the entire field received the same fertilizer and cultural treatment in 1940, it is obvious that such pronounced differences in favor of the manured strips can only be due to the residual effects of 10 years' fertilizer treatment of the field. In order to measure the changes which had been effected in the soil by the differential treatments for 10 years, samples from each of the plots were analyzed by the Soils Department. The analyses presented in Table 15 show the condition of the soil at the beginning of the 10 years in vegetables, 
the effects of 10 years of a commercial mixture, the effects of 40 tons of stable manure each year without any commercial, and the effects of half this amount of manure supplemented by 750 pounds of commercial mixture to the acre.

Acidity. Manured plots showed about the same $\mathrm{pH}$ readings as the commercial fertilizer plots. Both were considerably higher than the original soil. This was because lime had been added to the plots twice during the 10 years to provide favorable conditions for vegetable crops. Obviously the crop differences of 1940 cannot be ascribed to differences in acidity.

Organic matter. The differential treatments have produced differences in the percentage of organic matter in the soil. The use of a purely commercial fertilizer, containing only a minimum of organic ingredients, for 10 years, has reduced the organic matter 24 percent. The use of 20 tons of manure per acre has increased the organic matter by 7 percent, while 40 tons have made a difference of 21 percent. The heavily manured plot now has approximately 60 percent more organic matter than the plot treated with commercial mixture only.

Table 15. Comparative Solls Data on the Windsor Vegetable Plots. From soil samples taken in October, 1939, after ten years of treatments indicated.

\begin{tabular}{|c|c|c|c|c|}
\hline & $\begin{array}{l}40 \text { tons } \\
\text { of } \\
\text { stable } \\
\text { manure } \\
\text { per } \\
\text { acre }\end{array}$ & $\begin{array}{c}20 \text { tons } \\
\text { stable } \\
\text { manure } \\
\text { and } 750 \\
\text { lbs. of } \\
6-6-8 \\
\text { commer- } \\
\text { cial } \\
\text { ferti- } \\
\text { lizer } \\
\end{array}$ & $\begin{array}{c}1500 \text { lbs. } \\
\text { of a } \\
6-6-8 \\
\text { commer- } \\
\text { cial } \\
\text { ferti- } \\
\text { lizer }\end{array}$ & $\begin{array}{c}\text { Original } \\
\text { soil at } \\
\text { start of } \\
\text { the } 10 \\
\text { years }\end{array}$ \\
\hline Degree of acidity $(\mathrm{pH})$ & 6.11 & 6.12 & 6.14 & 5.30 \\
\hline Organic matter (5) & 2.62 & 2.32 & 1.64 & 2.17 \\
\hline $\begin{array}{l}\text { Total nitrogen (lbs. per A.) } \\
\text { (Kjeldahl method) }\end{array}$ & 2285 & 1865 & 1260 & 1750 \\
\hline $\begin{array}{l}\text { Phosphorus (lbs. per A.) ("available" } \\
\text { Truog method) }\end{array}$ & 508 & 498 & 380 & 448 \\
\hline Potassium (lbs. per A.) exchangeable & 349 & 319 & 221 & 228 \\
\hline Calcium (lbs. per A.) exchangeable & 1702 & 1587 & 1314 & 855 \\
\hline Magnesium (lbs. per A.) exchangeable & 238 & 176 & 97 & 70 \\
\hline
\end{tabular}

Total nitrogen. The total residual nitrogen (determined by Kjeldahl method) was reduced 28 percent by 10 years' treatment with commercial fertilizer alone; was increased 6 percent by 20 tons of manure, and increased 30 percent by 40 tons of manure. Total nitrogen on the high manure plot is now 81 percent higher than on the commercial fertilizer plot. 
Phosphorus. Available phosphorus (Truog method) was reduced 15 percent by 10 years of cropping with commercial fertilizer, but was increased 11 percent by 20 tons, and 13 percent by 40 tons, of manure. The difference between the commercial fertilizer plot and the high manure plot is now 33 percent.

Potassium. Exchangeable potassium was reduced slightly by the commercial fertilizer but was increased 40 percent by 20 tons, and 53 percent by 40 tons, of manure. The difference in potassium is now 58 percent in favor of the high manure plot.

Calcium. The differences in exchangeable calcium between the original and the present condition of the soil are mainly due to additions of lime. The present difference between the high manure plot and the commercial fertilizer plot is 30 percent in favor of the former.

Magnesium. The lime that was applied to these plots was high calcic, but the fertilizer treatments supplied some magnesia. At present, however, the soil on the high manure plot contains about 2.5 times as much magnesium as the commercial fertilizer plot.

The superiority of the crop on the manured plots is thus due to the higher level of fertility of the soil with respect to all the principal fertilizer elements: an increase of 81 percent in total nitrogen, 33 percent in available phosphorus, 58 percent in potassium, 30 percent in calcium, 150 percent in magnesium and 60 percent in organic matter.

\section{FURTHER EXPERIMENTS ON THE RELATION OF CALCIUM TO THE GROWTH OF TOBACCO}

T. R. SWANBACK

With the possible exception of the microflora, calcium is the most important factor in the soil in its effect on acidity and availability of phosphates and other nutrients, formation and structure of soils, and base exchange relationships.

Calcium is of equal importance to plant growth. It is essential to numerous functions within the plant which are continuously being studied on various crops. The following is a report on experiments designed to show the effect of calcium on growth and quality of tobacco.

\section{Experimental}

These experiments were undertaken in the spring of 1936 for the purpose of observing the effect of the element calcium on yield and quality (grading, burn and taste) of tobacco.

A series of plots was laid out on Field I on the experimental farm at Windsor. The soil here is of the Merrimac fine sandy loam type, of a mechanical analysis, averaging approximately as follows: 


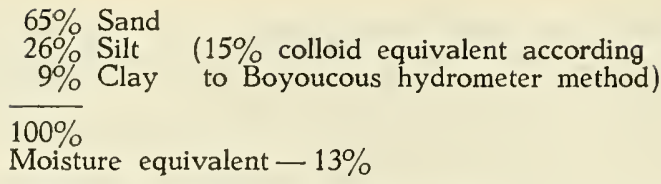

The relatively low moisture equivalent, in particular, indicates the low water retentive power of this soil which may be considered Composition of Fertilizer Mixtures for CALCIUM Experiments

\begin{tabular}{|c|c|c|c|c|c|c|c|}
\hline \multirow{2}{*}{$\begin{array}{l}\text { No special Ca-carrier } \\
\text { Name of material }\end{array}$} & \multirow{2}{*}{$\begin{array}{c}\text { Pounds per } \\
\text { Acre }\end{array}$} & \multicolumn{6}{|c|}{ Nutrients per acre } \\
\hline & & $\mathrm{N}$ & $\mathrm{P}_{2} \mathrm{O}_{5}$ & $\mathrm{~K}_{2} \mathrm{O}$ & $\mathrm{MgO}$ & $\mathrm{CaO}$ & $\mathrm{SO}_{3}$ \\
\hline \multirow{6}{*}{$\begin{array}{l}\text { Cottonseed meal } \\
\text { Urea } \\
\text { Soybean oil meal } \\
\text { Nitrate of potash } \\
\text { Sulfate of potash } \\
\text { Emjeo } \\
\text { Carbonate of potash }\end{array}$} & $\begin{array}{r}1800 \\
50\end{array}$ & 118 & 54 & 36 & 13 & 5 & 9 \\
\hline & 500 & 36 & 8 & 13 & 3 & 3 & \\
\hline & 200 & & & 88 & & & \\
\hline & 172 & & & 83 & & & 76 \\
\hline & $\begin{array}{r}250 \\
50\end{array}$ & & & 30 & 13 & $\gamma$ & \\
\hline & 3022 & 200 & 62 & 250 & 91 & 16 & 250 \\
\hline 100 Pounds $\mathrm{CaO}$ per acre & & & & & & & \\
\hline \multirow{7}{*}{$\begin{array}{l}\text { Cottonseed meal } \\
\text { Ulrea } \\
\text { Soybean oil meal } \\
\text { Nitrate of lime } \\
\text { Emjeo } \\
\text { Sulfate of potash } \\
\text { Carbonate of potash } \\
\text { Hydr. calc. lime }\end{array}$} & $\begin{array}{r}1800 \\
50\end{array}$ & $\begin{array}{r}118 \\
21\end{array}$ & 54 & 36 & 13 & 5 & 9 \\
\hline & 500 & 36 & 8 & 13 & 3 & 3 & \\
\hline & 250 & & & & 75 & 8 & 165 \\
\hline & 172 & & & 83 & & & 76 \\
\hline & 200 & & & 118 & & 30 & \\
\hline & & & & & & & \\
\hline & 3204 & 200 & 62 & 250 & 91 & 100 & 250 \\
\hline 300 Pounds $\mathrm{CaO}$ per acre & & & & & & & \\
\hline \multirow{8}{*}{$\begin{array}{l}\text { Cottonseed meal } \\
\text { Urea } \\
\text { Soybean oil meal } \\
\text { Nitrate of lime } \\
\text { Emjeo } \\
\text { Hydr. magn. lime } \\
\text { Sulfate of potash } \\
\text { Landplaster } \\
\text { Carbonate of potash } \\
\text { Hydr. calc. lime }\end{array}$} & $\begin{array}{r}1800 \\
50\end{array}$ & 118 & 54 & 36 & 13 & 5 & 9 \\
\hline & 500 & 36 & 8 & 13 & 3 & & \\
\hline & $\begin{array}{l}167 \\
125\end{array}$ & 25 & & & 38 & 45 & 83 \\
\hline & 160 & & & & 37 & 69 & \\
\hline & $\begin{array}{l}163 \\
205\end{array}$ & & & 78 & & 66 & $\begin{array}{l}72 \\
86\end{array}$ \\
\hline & 210 & & & 123 & & & \\
\hline & 185 & & & & & 115 & \\
\hline & 3565 & 200 & 62 & 250 & 91 & 300 & 250 \\
\hline 600 pounds $\mathrm{CaO}$ per acre & & & & & & & \\
\hline \multirow{7}{*}{$\begin{array}{l}\text { Cottonseed meal } \\
\text { Urea } \\
\text { Soybean oil meal } \\
\text { Nitrate of lime } \\
\text { Carbonate of potash } \\
\text { Landplaster } \\
\text { Hydr. magn. lime } \\
\text { Hydr. calc. lime } \\
\text { Emjeo }\end{array}$} & $\begin{array}{r}1800 \\
50\end{array}$ & 118 & 54 & 36 & 13 & 5 & 9 \\
\hline & 500 & 36 & 8 & 13 & 3 & & \\
\hline & $\begin{array}{l}167 \\
330\end{array}$ & 25 & & 201 & & 45 & \\
\hline & 560 & & & & & 179 & 241 \\
\hline & $\begin{array}{l}100 \\
530\end{array}$ & & & & 23 & $\begin{array}{r}43 \\
328\end{array}$ & \\
\hline & 140 & & & & 52 & & \\
\hline & 4177 & 200 & 62 & 250 & 91 & 600 & 250 \\
\hline
\end{tabular}


as fairly typical of tobacco land on the west side of the Connecticut river.

The reaction of the soil at the beginning of the test was $\mathrm{pH} 4.8$ with a correspondingly low content of replaceable calcium, according to Morgan's method. On the other hand, there was abundant supply of available phosphoric acid, replaceable potash, and a fair amount of magnesia.

The plots, sufficient for duplicate treatments (size one twentyfifth acre), were fertilized according to schedule, given above.

From these schedules it is seen that three different quantities of $\mathrm{CaO}$ were used $(100,300$ and 600 pounds $\mathrm{CaO}$ per acre) in comparison with plots receiving no calcium, except the small amount in the organics.

In order to minimize changes in the soil reaction, calcium was supplied from nitrate, sulfate and hydrate, with nitrates and sulfates kept as constant as possible for all plots. According to calculations, using generally accepted values for the materials (Pierre's) the following acidic or basic effects from the treatments for the four years would be anticipated.

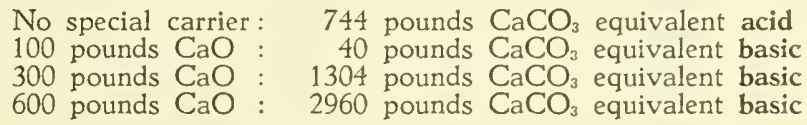

But at the termination of the entire experiment, the plots with the highest applications of calcium showed reactions 0.3 to $0.4 \mathrm{pH}$-unit above the original values.

During the four years of these experiments, there was considerable variation of rainfall; the season of 1936 was relatively dry; 1937 was fairly wet, and 1938 extremely wet. With the exception of slight hail damage to the crop of 1939, weather conditions during that season were satisfactory.

The crop of 1936 was irrigated once and additional nitrogen had to be furnished to the crop of 1938 .

Yield and grading. In the four-year period the average length of the growing season was 74 days, approximately average for this type of tobacco (Havana Seed) in the Connecticut Valley. Each season sets an ear-mark on the crop, $i$. e., weather conditions play an important part in determining yield and quality. In Table 16 the weighted average yield, irrespective of treatment, and grade indexes for the four-year period are given and compared with similar data for each year. From this it seems that the yield for 1936 increased about 27 percent with no effect on the grading. The crop of 1937 increased about 11 percent above the average and the grading was improved more than 17 percent.

On the other hand, with excessive rainfall in 1938, the yield figure was about 75 percent and the grading about 40 percent below 
the average. In 1939, yields were up 5 percent and grading 10 percent above average.

Finally, in reducing the effects to single values and taking the four-year average as 100 , we find that the 1936 crop has a value of 127; the increase due only to a greater than average yield. The value of the 1937 crop, 130, was due to improvement in both yield and quality, and so on.

The effect of the various calcium additions under a tobacco crop on yield and grading is found in Table 17. cium.

Yields were very little affected, if any, by the additions of cal-

The grading, however, seems to improve with additions of this element, reaching optimum at 300 pounds $\mathrm{CaO}$ per acre.

Table 16. Seasonal Effect on Yield and Grading.

\begin{tabular}{c|c|c|cc|c}
\hline \hline Year & $\begin{array}{c}\text { Average } \\
\text { yields. } \\
\text { pounds }\end{array}$ & $\begin{array}{c}\text { Percent } \\
\text { variation, } \\
\text { approx. }\end{array}$ & $\begin{array}{c}\text { Grade } \\
\text { index }\end{array}$ & $\begin{array}{c}\text { Percent } \\
\text { variation }\end{array}$ & $\begin{array}{c}\text { Relative } \\
\text { crop } \\
\text { value }\end{array}$ \\
\cline { 2 - 5 } 1936 & 2346 & +27 & .370 & & 127 \\
1937 & 2046 & +11 & .437 & +17 & 130 \\
1938 & 1053 & -75 & .269 & -40 & 41 \\
1939 & 1926 & +5 & .409 & +10 & 115 \\
\hline 4-year average & $\mathbf{1 8 4 2}$ & & .372 & & 100 \\
\hline \hline
\end{tabular}

${ }^{1}$ Relative crop values were obtained by multiplying the yield figures with those of the grade indexes and assuming a value of 100 for the four-year average

Table 17. Yield and Grading Records, Four-Year Summary of CALCIUM EX́PERIMENT.

\begin{tabular}{|c|c|c|c|c|c|c|c|c|c|c|c|}
\hline \multirow{2}{*}{$\begin{array}{l}\text { Pounds } \\
\text { CaO } \\
\text { per A. }\end{array}$} & \multicolumn{5}{|c|}{ Yield, pounds per acre } & \multicolumn{5}{|c|}{ Grade index } & \multirow{2}{*}{$\begin{array}{l}\text { Crop } \\
\text { index }\end{array}$} \\
\hline & 1936 & 1937 & 1938 & 1939 & Av. & 1936 & 1937 & 1938 & 1939 & Av. & \\
\hline None & 2275 & 1862 & 1043 & 1968 & 1787 & 352 & .385 & .264 & .404 & .351 & 627.24 \\
\hline 100 & 2453 & 2073 & 1061 & 1969 & 1889 & .360 & .432 & .273 & .406 & 368 & 695.15 \\
\hline 300 & 2297 & 2118 & 1019 & 1885 & 1830 & .366 & .470 & .293 & .409 & .387 & 708.21 \\
\hline 600 & 2358 & 2130 & 1089 & 1877 & 1863 & .403 & .465 & .246 & .416 & .383 & 713.53 \\
\hline
\end{tabular}

Relative crop values

$$
\begin{aligned}
& \text { No. CaO }=100 \\
& 100 \mathrm{lbs} " ،=110.8 \\
& 300 " ، " “=112.9 \\
& 600 " ،=113.7
\end{aligned}
$$

Taking into consideration both yield and grading, there is a definite trend toward improvement in crops as suggested by the crop indexes and the relative crop values. In other words, a crop to which ample amounts of calcium have been added would sell better 
or give a better return than one which had been neglected in this respect, other things being equal.

Grades. The various grades into which Havana Seed tobacco is sorted are called: lights (L), mediums (M), long seconds (LS), short seconds (SS), long darks (LD), dark stemming (DS), fillers (F) and brokes (B). A description of these grades has been presented in earlier publications of this Station (See in particular Bul. 422, p. $22 \mathrm{ff}$.$) .$

In Table 18 a three-year summary is given, showing the yield and grading trends during the course of the experiment. ${ }^{1}$ While lights are steadily increasing with increased applications of calcium, the percentage of long darks decreases.

From our nitrogen experiments, published previously (Bul. 410, p. $335 \mathrm{ff}$.) we have learned that the percentage of darks increases with increased applications of nitrogen. In this connection, it should be mentioned that calcium is most freely absorbed as nitrate (Station Bul. 350, p. $476 \mathrm{ff}$.). Also, it may be expected that as the calcium in the soil increases, the portion taken up as nitrate might be relatively increased (see further under "Total nitrogen", page 257).

Since nitrates are easily translocated within the plant, nitrogen in this form is less apt to accumulate in the leaves than other forms

Table 18. Yield and Grading Records of Calcium Plots. SuMMARY OF THREe Years.

\begin{tabular}{|c|c|c|c|c|c|c|c|c|c|c|c|}
\hline \multirow{2}{*}{$\begin{array}{l}\text { Pounds } \\
\text { CaO } \\
\text { per A. }\end{array}$} & \multirow{2}{*}{$\begin{array}{l}\text { Yield } \\
\text { pounds } \\
\text { per A. }\end{array}$} & \multicolumn{8}{|c|}{ Percentage of grades } & \multirow{2}{*}{ Grade index } & \multirow{2}{*}{$\begin{array}{l}\text { Relative } \\
\text { crop } \\
\text { value }\end{array}$} \\
\hline & & $\mathrm{I}$ & In & LS & $\mathrm{SS}$ & $\mathrm{LD}$ & DS & $\mathrm{F}$ & B & & \\
\hline $\begin{array}{c}\text { None } \\
100 \\
300 \\
600\end{array}$ & $\begin{array}{l}2035 \\
2166 \\
2100 \\
2122\end{array}$ & $\begin{array}{l}1 \\
2 \\
3 \\
4\end{array}$ & $\begin{array}{l}3 \\
4 \\
5 \\
5\end{array}$ & $\begin{array}{l}31 \\
33 \\
33 \\
34\end{array}$ & $\begin{array}{l}4 \\
4 \\
5 \\
5\end{array}$ & $\begin{array}{l}48 \\
46 \\
43 \\
41\end{array}$ & $\begin{array}{l}2 \\
1 \\
1 \\
1\end{array}$ & $\begin{array}{l}8 \\
7 \\
8 \\
8\end{array}$ & $\begin{array}{l}3 \\
3 \\
2 \\
2\end{array}$ & $\begin{array}{l}.385 \\
.404 \\
.414 \\
.424\end{array}$ & $\begin{array}{l}100 \\
111.7 \\
111.0 \\
114.8\end{array}$ \\
\hline
\end{tabular}

of nitrogen. Moreover, from our tests with nitrate of soda we have found that this material produces a lower percentage of darks than other inorganics and many organics. Hence, it may be assumed that production of darks will be limited if the uptake of nitrates is encouraged.

\section{Effect on Burn}

Strip burn tests. Samples of the 1936 crop were submitted to

${ }^{1}$ The data for 1938 is omitted because of rain damage to the growing crop. 
tests on the duration of burn (glow) of the leaf, once it is ignited. The results are listed below:

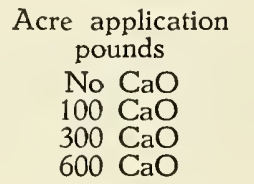

Duration of burn
seconds
38
39
27
30

These figures represent the average of both darks and seconds. It is evident that the lowest application of calcium $(100 \mathrm{CaO})$ did not impair burn, while the other increments somewhat reduced the fire holding capacity. The explanation of this will be found under the discussion of chemical analyses.

Cigar tests. Commercial cigars were wrapped with leaves from the 1936 crop. Although the ash color was improved with each addition of calcium, a muddy color, most intensive on the no-calcium treatment, was not entirely masked on cigars from the highest addition of calcium. The taste, however, improved with each increment of $\mathrm{CaO}$ added to the soil.

Leaves from the 1939 crop were wrapped on cigars made up by an experienced cigar maker. Particular care was taken to have the binders (re-sweated Broadleaf) and fillers (Cuban) as uniform as possible in all cigars. In this test the muddy ash color was of a lighter shade than in the 1936 crop, except in two instances. The no-calcium samples were possibly darker, and the highest addition of $\mathrm{CaO}$ gave ash that was light gray. In other respects also, cigars from this last treatment differed from the rest in that the coal band was very narrow, all others being quite wide. Moreover, the taste of these cigars was superior to that of the other samples. This opinion was unanimous among smokers who tested the cigars.

\section{Chemical Analyses}

Samples from the 1936 crop were analyzed for various constituents. Darks and seconds were selected in order to get an approximate value of the whole plant. In the following, each constituent is discussed separately.

Calcium. Calcium increased in the plant somewhat in proportion to amounts added to the soil, as may be gathered from Table 19.

An average curve, plotted from the above data, would follow an almost straight line. Moreover, it is indicated that still higher applications of calcium than 600 pounds $\mathrm{CaO}$ per acre would have been necessary to cause a deflection in the curve, $i$. e., before an optimum absorption of this element has been reached.

Magnesium. When calcium is on an upward trend, it is to be expected that the magnesium content would go in the other direction, according to previous findings. ${ }^{1}$ However, in Table 20 we find

${ }^{1}$ Swanback, T. R. Studies on antagonistic phenomena and cation absorption in tobacco in the presence and absence of manganese and boron. Plant Phys. 14: 423-446. 1939. 
that not until $600 \mathrm{CaO}$ per acre had been supplied to the plants was there an appreciable decrease in the magnesia content. Calcium is weakly antagonistic ${ }^{1}$ to magnesia, retarding the absorption by plants of this latter element. The antagonistic action of calcium, however, must also come into play against other bases. Therefore, its effect on magnesium was not apparent until mass action of calcium was reinforced, when more calcium was available in the soil.

Table 19. Calcium Content of Tobacco Grown With Various QuANTities of CAO. Air-Dried Basis.

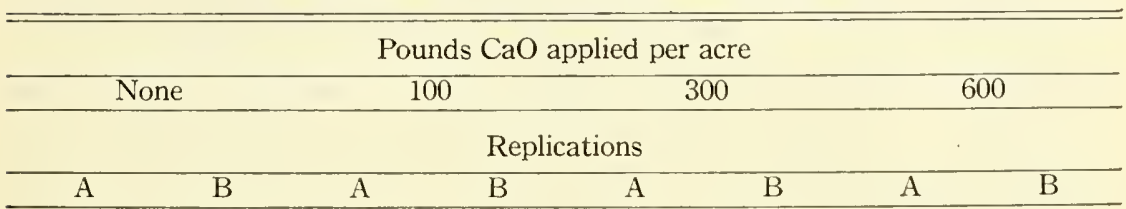

Grades

\begin{tabular}{|c|c|c|c|c|c|c|c|c|c|}
\hline $\mathrm{D}$ & $\mathrm{S}$ & $\mathrm{D}$ & $\mathrm{S}$ & $\mathrm{D}$ & S & $\mathrm{D}|\mathrm{S}| \mathrm{D}|\mathrm{S}| \mathrm{D}|\mathrm{S}| \mathrm{D}$ & $\mathrm{S}$ & $\mathrm{D}$ & $\mathrm{S}$ \\
\hline & & & & & & Percentage of $\mathrm{CaO}$ in the leaves & & & \\
\hline 02 & .80 & 4.32 & 0.00 & 4.42 & 5.60 & $4.42|6.02| 4.86|6.40| 5.20|6.64| 5.54$ & 6.40 & 5.70 & 7.99 \\
\hline
\end{tabular}

Average percent $\mathrm{CaO}$ per treatment

\begin{tabular}{cccc}
\hline $\mathbf{4 . 6 7}$ & $\mathbf{5 . 1 2}$ & $\mathbf{5 . 8 0}$ & $\mathbf{6 . 4 1}$ \\
\hline & Approximate relative absorption of calcium \\
\hline 100 & 110 & 120 & 130 \\
\hline
\end{tabular}

Table 20. Magnesium Content of Tobacco Grown With Various Quantities of CaO. Air-Dried Basis.

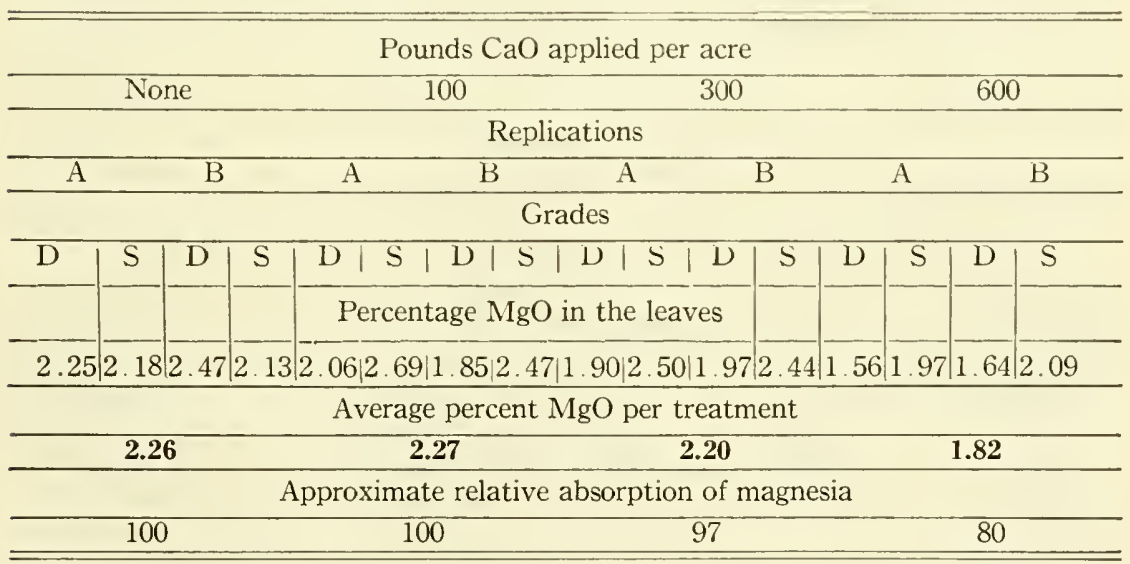

"Antagonism" refers to the action of an ion of one element upon an ion of another element, while pseudo-antagonism will occur when the concentration of one kind of ions is greater than that of the other. 
Potassium. While calcium is weakly antagonistic to magnesium, it possesses only pseudo-antagonistic qualities against potassium; i.e., it is effective when available calcium is present in higher concentration in the soil solution than potassium. This latter is evident from Table 21, in which we find that increasing calcium in the soil causes potassium gradually to decrease in the leaf. Since potash is the most important agent in promoting fire holding capacity, it is easily seen that lowering the potash adversely affects the burn.

It is apparent that with a greater calcium absorption, an an tagonism was directed toward magnesium rather than a pseudoantagonism against potassium (see Table 20). In this connection it may be pointed out, as in earlier reports of this Station, that an acid-base balance is always endeavoring to establish itself within the plant. The main bases, calcium, magnesium and potassium, are attempting to meet a certain requirement and, so to speak, need mutual assistance. This is remarkably well demonstrated in the summary of Table 22.

Table 21. Potassiun Content of Tobacco Grown With Various Quantities of CaO. AIr-Dried Basis.

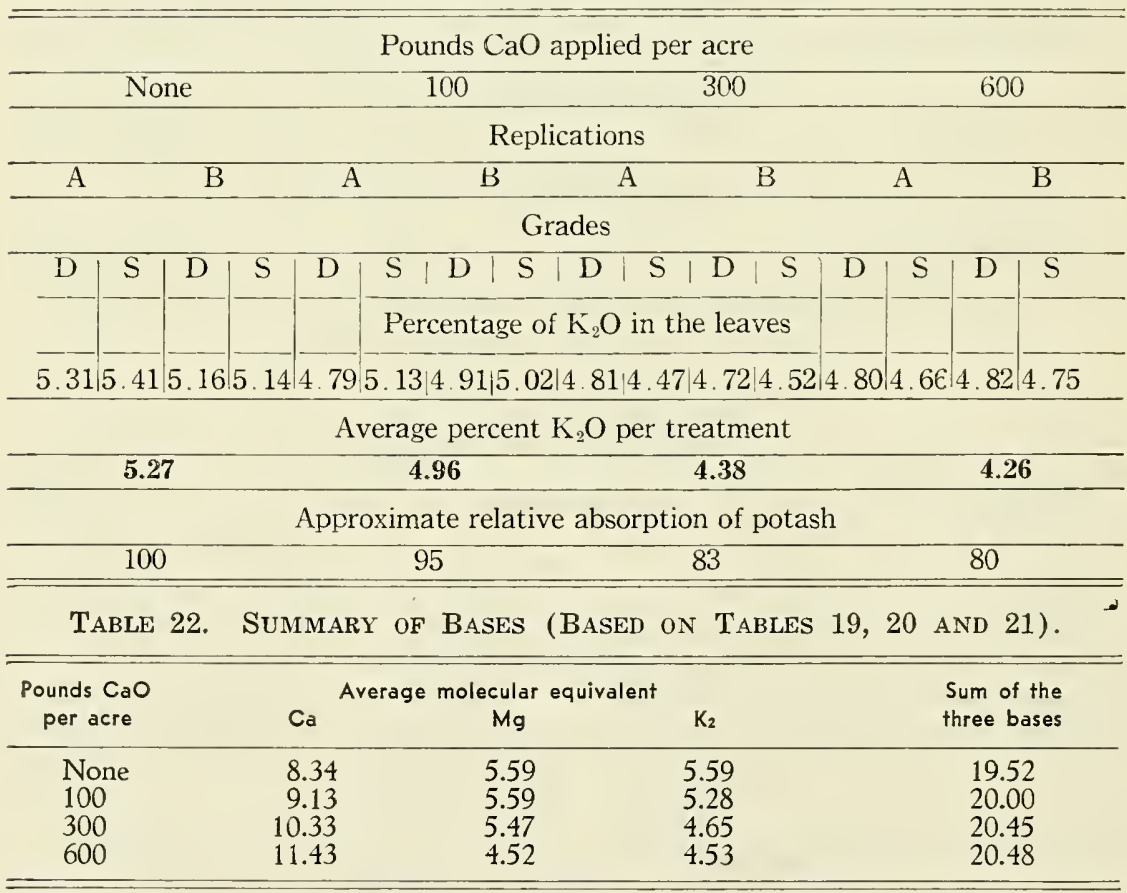

It is seen that the sum of the bases as calculated in their molecular equivalents is nearly constant; at least the variation is not larger than could be expected, allowing for experimental errors. 
Phosphorus. In order to observe the possible effects of calcium on the deposition of phosphorus in the leaves, analyses for this element were also undertaken. However, since no marked difference, due to the various $\mathrm{Ca}$ applications, appeared, the average results only are given (Table 23).

Table 23. Sumiary of Phosphorus Analyses

\begin{tabular}{lllll}
\hline \multicolumn{1}{c}{$\begin{array}{c}\text { Application of } \mathrm{CaO} \\
\text { Pounds per acre }\end{array}$} & None & 100 & 300 & 600 \\
\hline Av. $\%$ of $\mathrm{P}_{2} \mathrm{O}_{5}$ in the leaf & .415 & .449 & .422 & .434 \\
Av. $\%$ of $\mathrm{P}_{2} \mathrm{O}_{5}$ of & & & & \\
All darks & & .542 & \\
All seconds & .317 & \\
\hline
\end{tabular}

The darks, in conformity with previous investigations (Tobacco Exp. Sta. Bul. 7: 14, 1927), contained about 70 percent more phosphoric acid than the seconds.

Nitrogen. Results from analyses on total nitrogen and some of the nitrogen fractions (nitric nitrogen. ammonia and nicotine) are found in Table 24.

Total nitrogen. Since nitrogen was not a variable, it would not be expected that this element in the leaves should fluctuate according to the different calcium applications. On the other hand, in previous investigations ${ }^{1}$ in which the nitrogen was varied, increasing nitrogen in the soil not only resulted in larger amounts of nitrogen in the leaves but also of calcium, due to greater supply of soil nitrates; molar equivalents of calcium matched reasonably well those of nitrogen. Reversely, it may be assumed that with increasing available calcium in the soil (nitrogen constant) more nitrogen would be absorbed in the form of nitrates. Its effect on grading is discussed earlier.

Nitric nitrogen in the leaves may be considered of little significance in a cured leaf. unless of sufficient magnitude to cause the leaf to burn with audible explosions. This type of nitrogen may be thought of as residual, that is, a part of the absorbed nitrogen, not used up in the metabolic functions.

${ }^{1}$ Sta. Bul. 410: 349. 
Table 24. Various Nitrogen Constituents in Tobacco. ${ }^{1}$

\begin{tabular}{|c|c|c|c|c|c|c|c|c|c|c|c|}
\hline \multirow{2}{*}{$\begin{array}{c}\mathrm{CaO} \\
\text { per } \\
\text { acre } \\
\end{array}$} & \multirow{2}{*}{ Grade } & \multirow{2}{*}{\multicolumn{2}{|c|}{$\begin{array}{l}\text { Total nitrogen } \\
\text { ¿s N Av. }\end{array}$}} & \multirow{2}{*}{\multicolumn{2}{|c|}{$\begin{array}{c}\text { Nitric nitrogen } \\
\text { as } \mathrm{NO} \\
\% \quad \text { Av. } \\
\end{array}$}} & \multirow{2}{*}{\multicolumn{2}{|c|}{$\begin{array}{c}\text { Ammonia nitr' }{ }^{\prime} \mathrm{n} \\
\text { as } \mathrm{NH}_{3} \\
\text { Av. }\end{array}$}} & \multicolumn{2}{|c|}{ Nicotine } & \multicolumn{2}{|c|}{$\mathrm{NH}_{3} /$ nicotine $\mathrm{x} 10$} \\
\hline & & & & & & & & $\%$ & Av. & Ratio & Av. \\
\hline None & $\begin{array}{ll}\mathrm{A} & \mathrm{D} \\
\mathrm{A} & \mathrm{S} \\
\mathrm{B} & \mathrm{D} \\
\mathrm{B} & \mathrm{S}\end{array}$ & $\begin{array}{l}5.11 \\
3.38 \\
5.04 \\
3.46\end{array}$ & 4.25 & $\begin{array}{l}1.59 \\
1.69 \\
1.64 \\
3.72\end{array}$ & 2.16 & $\begin{array}{r}1.41 \\
.73 \\
1.37 \\
.68\end{array}$ & 1.05 & $\begin{array}{l}3.85 \\
3.07 \\
4.44 \\
3.35\end{array}$ & 3.68 & $\begin{array}{l}3.66 \\
2.38 \\
3.08 \\
2.03\end{array}$ & 2.79 \\
\hline 100 & $\begin{array}{ll}\mathrm{A} & \mathrm{D} \\
\mathrm{A} & \mathrm{S} \\
\mathrm{B} & \mathrm{D} \\
\mathrm{B} & \mathrm{S}\end{array}$ & $\begin{array}{l}4.79 \\
3.45 \\
5.24 \\
3.22\end{array}$ & 4.17 & $\begin{array}{r}.75 \\
1.82 \\
2.57 \\
1.37\end{array}$ & 1.63 & $\begin{array}{r}1.52 \\
.56 \\
1.55 \\
.52\end{array}$ & 1.04 & $\begin{array}{l}3.94 \\
3.27 \\
4.80 \\
3.27\end{array}$ & 3.82 & $\begin{array}{l}3.86 \\
1.71 \\
3.22 \\
1.59\end{array}$ & 2.59 \\
\hline 300 & $\begin{array}{ll}\mathrm{A} & \mathrm{D} \\
\mathrm{A} & \mathrm{S} \\
\mathrm{B} & \mathrm{D} \\
\mathrm{B} & \mathrm{S}\end{array}$ & $\begin{array}{l}5.42 \\
3.28 \\
5.00 \\
3.38\end{array}$ & 4.26 & $\begin{array}{l}2.39 \\
1.51 \\
1.20 \\
1.82\end{array}$ & 1.73 & $\begin{array}{r}1.78 \\
.51 \\
1.41 \\
.39\end{array}$ & 1.02 & $\begin{array}{l}4.31 \\
3.20 \\
4.45 \\
3.42\end{array}$ & 3.84 & $\begin{array}{l}4.13 \\
1.59 \\
3.17 \\
1.14\end{array}$ & 2.50 \\
\hline 600 & $\begin{array}{ll}\mathrm{A} & \mathrm{D} \\
\mathrm{A} & \mathrm{S} \\
\mathrm{B} & \mathrm{D} \\
\mathrm{B} & \mathrm{S}\end{array}$ & $\begin{array}{l}5.30 \\
3.36 \\
4.28 \\
3.22\end{array}$ & 4.04 & $\begin{array}{l}4.56 \\
1.69 \\
1.46 \\
2.97\end{array}$ & 2.67 & $\begin{array}{r}1.22 \\
.53 \\
1.37 \\
.19\end{array}$ & .83 & $\begin{array}{l}4.49 \\
3.39 \\
4.60 \\
2.95\end{array}$ & 3.86 & $\begin{array}{r}2.71 \\
1.56 \\
3.97 \\
.64\end{array}$ & 2.22 \\
\hline
\end{tabular}

${ }_{1}$ The author is indebted to Dr. E. M. Bailey for these analyses.

Ammonia. This form of nitrogen may also be considered residual. It is an intermediate form, created during the transition of nitrates to various protein substances or other complicated forms of nitrogen. Therefore, it can be assumed that the less ammonia there is present in the leaf, the closer the leaf would have approached the stage of completion of the nitrogen transformation. In other words, the leaf reaches maturity.

This is somewhat borne out by the analyses (Table 24). There is from two to six times as much ammonia in the darks as in the seconds. Moreover, there is a tendency of the ammonia to decrease with increasing applications of calcium. This suggests that the presence of calcium facilitates the transition of ammonia into other nitrogenous compounds.

Nicotine is practically constant in the leaves, depending on position in the stalk. It has been shown previously ${ }^{1}$ that nicotine increases in the leaves from the bottom of the plant to about twothirds up the stalk, after which it remains fairly constant.

The darks contain an average of 4.36 percent nicotine and the individual data do not deviate appreciably from this average. The same is true for the seconds, with an average of 3.24 percent nicotine.

${ }^{1}$ Hanmer, H. R., O. E. Street and P. J. Anderson. Variation in chemical composition of cured tobacco leaves according to their position on the stalk. Conn. Agr. Expt. Sta. Bul. 433: 179. 
It is generally known that the nicotine in a cigar determines its strength, that is, the smoker judges as strong the cigar in which nicotine predominates. On the other hand, if the cigar produces a sharp taste, "bite", it is generally accepted that free ammonia is the cause.

When used in a cigar, darks invariably produce more of a bite than seconds. This is reflected in the ammonia content of the two grades (Table 24).

Since ammonia is to be considered as transitory, while nicotine is a finished product, a ratio between the two may be established. This might be a criterion on which to judge how far the maturing processes had gone in a leaf and, with cured and fermented tobacco on cigars, it might be correlated with taste.

In the last column of Table 24 we find that the ratio $\mathrm{NH}_{3}$ $\times 10 /$ nicotine is considerably higher for the darks than for the seconds. The average, irrespective of treatments, is 3.48 for the darks and only 1.58 for the seconds. Darks rolled on to cigars have a taste far inferior to that of seconds. From this we deduct that improvement in taste is correlated with a decreasing ratio.

Incidentally, there seems to be a slight decrease in the average ratios with increasing calcium applications. It is indicated, at least, that there is significant difference between applications of 600 pounds $\mathrm{CaO}$ per acre and none at all. From this it may be concluded that calcium per se improves the smoking qualities of cigar leaf tobacco. (See discussion under "cigar test").

\section{Discussion and Conclusions}

The effect of calcium on tobacco has been studied by means of field plots. Increments of 100,300 and 600 pounds $\mathrm{CaO}$ per acre as used in the trials were probably not great enough to have a decided effect in a single year. However, with larger increments the accumulative effects might have been too great for a continuation of the experiments on the same plots. The results suggest that after four years the highest application of calcium about satisfied the need of calcium as balanced against other bases. From 1,800 to 2,400 pounds $\mathrm{CaO}$ per acre, added to the original very low content of calcium in the soil, were needed to obtain a proper balance between calcium and other bases, potash and magnesia. These, incidentally, corresponded to a "medium" to "medium high" reading according to our well-established soil testing method $^{1}$. In numerous cases the writer in conferences with growers has gathered that most satisfactory results were obtained on tobacco soils in which the calcium content proved to be medium to medium high.

When a soil is depleted in calcium, it is not to be recommended that the entire need be satisfied in one application. It is possible that minor elements may be tied up in the soil. If, for instance, the soil

${ }^{1}$ Morgan, M. F. Universal soil testing system. Bul. 392 and Circ. 127. Conn. Agr. Expt. Sta. 
reaction is $\mathrm{pH} 4.6$, enough lime may be added to raise the $\mathrm{pH}$ value to a proper level, pH 5.2 to 5.4, for example. From 600 to 800 pounds hydrated lime per acre will produce this change in reaction on sandy soils with low to medium organic matter content. Furthermore, landplaster may be added up to 500 pounds per acre. In this way, from 500 to 600 pounds actual $\mathrm{CaO}$ per acre would be added. Incidentally, some calcium is also added in various fertilizer materials. Thus, the pertinent need for one season is satisfied. The calcium level should be observed the following season, making the proper corrections if needed. These recommendations are made with the provision that the soil content of other bases, particularly potash, is satisfactory.

This latter point is very important, since an endeavor to improve the calcium status in a soil of low potash content leads to further impairment of the burn of the leaf. Results from the chemical analyses show that an increase of calcium in the soil somewhat decreased the potash in the leaves even under conditions of a relatively high potash level in the soil. Therefore, soils low in potash, such as new land (new to tobacco), must have liberal applications of potash materials at the time attempts are made to rectify the calcium content.

While improvement in grading and sometimes in yield was effected with calcium additions to the land, the taste of tobacco was improved to considerable extent, only when the highest amount of $\mathrm{CaO}$ per acre (600 pounds) had been used for several years. This means that the individual grower might not succeed in getting all the qualities in improvement that he anticipates in one year. $\mathrm{He}$ will, however, gradually improve the crop by careful planning and sampling of the soil.

\section{STARTER SOLUTIONS}

The method of using a "starter" (quickly available plant food) has long been popular with the tobacco grower. Our experiments (Conn. Sta. Bul. 391: 79), however, have shown that inclusion of nitrates in the fertilizer mixtures, applied before setting, gives results of no significant difference from those with no nitrates. This is probably due to the. fact that nutrient requirements of the young plants are equally well satisfied by the nitrates, gradually derived from organic sources, as by the limited amount of nitrate material that can be included in a mixture. In fact, a very small fraction of this material would come in direct contact with the limited root system of the young plants.

One means to remedy this condition would be to furnish each individual plant with nitrates in solution form, such as adding a small quantity of nitrates in the water of the setter barrel. Another way, as often practiced by the grower, is to withhold a portion of the total mixture intended for a field, and apply it later as a side-dressing at the time of first or second hoeing.

Recently, commercial starter solutions have appeared on the 
market, some of which contain growth promoting substances, either alone or with complete nutrients. Great claims have been made for those solutions on crops other than tobacco, especially in overcoming the transplanting shock of young seedlings.

For the purpose of observing how starter solutions would affect tobacco, a limited experiment was made in the spring of 1940.

To three one-twenty-fifth acre plots, each with six rows of tobacco, the equivalents of 175 pounds of nitrogen, 90 pounds of phosphoric acid $\left(\mathrm{P}_{2} \mathrm{O}_{5}\right)$ and 175 pounds of potash $\left(\mathrm{K}_{2} \mathrm{O}\right)$ per acre were applied, that is, a portion corresponding to 25 pounds of nitrogen, and other plant food, in proper ratio was withheld.

This portion was later added as a side-dressing to three rows in each plot. One of these rows from each plot was later harvested as check.

The other three rows in each plot were each treated as follows:

Row 1. Nitrogen to the equivalent of 25 pounds per acre, and, in the form of nitrate of soda added to the water at time of setting.

Row 2. Nitrogen and potash in the form of nitrate of potash, similarly added to the water.

Row 3. Nitrogen, phosphoric acid and potash from a mixture made up as follows:

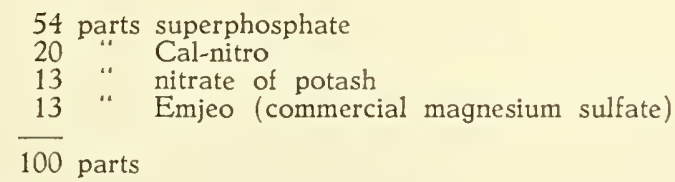

This mixture was used at the rate of 22 pounds to 100 gallons of water.

Eight pounds each of nitrate of soda and nine pounds nitrate of potash per 100 gallons of water were used for solutions 1 and 2 , respectively.

About one-half pint of the solution was applied to each plant.

All plants receiving plant food in solution form seemed to suffer a setback in growth as compared with check rows, suggesting that the solutions were too strong. Most severe injury occurred on the nitrate of soda treatment. At time of harvest, however, no marked differences in growth between the various treatments could be observed. It seems advisable, however, to cut down the strength of the solutions by one-third.

The crop was harvested on August 17. Data obtained from sorting in November are found in Table 25. 
Table 25. Yield and Grading Records of Tobacco Grown With Starter Mixtures. Crop of 1940.

\begin{tabular}{|c|c|c|c|c|c|c|c|c|c|c|c|c|c|c|}
\hline \multirow[t]{2}{*}{ Treatment } & \multirow[t]{2}{*}{ Plot } & \multicolumn{2}{|c|}{$\begin{array}{l}\text { Yield } \\
\text { per acre }\end{array}$} & \multicolumn{8}{|c|}{ Percentage of grades } & \multicolumn{2}{|c|}{$\begin{array}{l}\text { Grade } \\
\text { index }\end{array}$} & \multirow{2}{*}{$\begin{array}{l}\text { Rela- } \\
\text { tive } \\
\text { crop } \\
\text { value }\end{array}$} \\
\hline & & Plot & $\overline{A v}$. & L & $\mathbf{M}$ & $\mathrm{LS}$ & SS & LD & DS & $\mathrm{F}$ & B & Plot & Av. & \\
\hline $\begin{array}{c}\text { No } \\
\text { starter } \\
\text { solution }\end{array}$ & $\begin{array}{l}\mathrm{A} \\
\mathrm{B} \\
\mathrm{C}\end{array}$ & $\begin{array}{l}2000 \\
1957 \\
1964\end{array}$ & 1974 & 5 & 3 & $\begin{array}{l}41 \\
39 \\
40\end{array}$ & 6 & $\begin{array}{l}30 \\
30 \\
30\end{array}$ & $\begin{array}{l}3 \\
6 \\
8\end{array}$ & $\begin{array}{l}8 \\
8 \\
7\end{array}$ & 3 & $\begin{array}{l}.468 \\
.433 \\
.433\end{array}$ & .445 & 100.0 \\
\hline Nitrogen & $\begin{array}{l}A \\
B \\
C\end{array}$ & $\begin{array}{l}1897 \\
2011 \\
1935\end{array}$ & 1948 & 6 & 1 & $\begin{array}{l}35 \\
38 \\
34\end{array}$ & 9 & $\begin{array}{l}38 \\
31 \\
26\end{array}$ & $\begin{array}{r}3 \\
9 \\
13\end{array}$ & $\begin{array}{l}9 \\
7 \\
7\end{array}$ & 3 & $\begin{array}{l}.416 \\
.416 \\
.417\end{array}$ & .416 & 92.4 \\
\hline $\begin{array}{l}\text { Nitrogen \& } \\
\text { potash }\end{array}$ & $\begin{array}{l}\text { A } \\
\text { B } \\
\text { C }\end{array}$ & $\begin{array}{l}1792 \\
1900 \\
1845\end{array}$ & 1846 & 5 & - & $\begin{array}{l}33 \\
39 \\
42\end{array}$ & 5 & $\begin{array}{l}35 \\
33 \\
27\end{array}$ & $\begin{array}{r}4 \\
9 \\
12\end{array}$ & $\begin{array}{l}9 \\
8 \\
8\end{array}$ & 5 & $\begin{array}{l}.415 \\
.425 \\
.413\end{array}$ & .418 & 85.6 \\
\hline $\begin{array}{l}\text { Nitrogen } \\
\text { Phosphorus } \\
\text { Potash }\end{array}$ & $\begin{array}{l}\mathrm{A} \\
\mathrm{B} \\
\mathrm{C}\end{array}$ & $\begin{array}{c}1708 \\
1868 \\
1728\end{array}$ & 1768 & 2 & 1 & $\begin{array}{l}36 \\
40 \\
39\end{array}$ & 5 & $\begin{array}{l}35 \\
28 \\
26\end{array}$ & $\left|\begin{array}{r}7 \\
7 \\
11\end{array}\right|$ & $\begin{array}{r}10 \\
8 \\
10\end{array}$ & 9 & $\begin{array}{l}.369 \\
.396 \\
.372\end{array}$ & .379 & 76.4 \\
\hline
\end{tabular}

It is evident from these data that the method of saving a portion of the fertilizer and applying it as a side-dressing at time of second hoeing is a safer procedure than using starter solutions. The least benefit was derived from the "complete" solution. In the last column of the table, relative crop values ${ }^{1}$ are indicated.

Where nitrogen only was added in solution form there was a slight decrease in crop value; with two elements (nitrogen and potash) there was further decrease, while most severe decrease was caused by adding the three elements, N, P and K. This suggests that the salt concentrations were too high and that dilution should be made on the basis of salt concentration and not, as in the present case, on the basis of nitrogen.

\section{Commercial Starter Solutions}

In an adjacent field a few commercially available starter solutions were tested. Since some of these have direct fertilizer value, and others furnish only "growth promoting" substances, such as hor-

${ }^{1}$ Relative crop values are obtained by multiplying the yield figure by the grade index (= crop index) and arbitrarily considering the value obtained from the check plots as 100 . 
mones or vitamins, half of the field was fertilized in the usual way for growing a crop of tobacco and the remainder received no fertilizer.

Rows of tobacco ran through both fertilized and unfertilized parts. At time of planting, each individual plant received a portion of the various solutions (five in all) as directed by the several manufacturers, except check rows.

Due to the wet weather at time of planting, there was not much wilting of the plants. Hence no observation could be made on the transplanting shock. During the growing season, solutions number 3 and 4 appeared to cause more vigorous growth than the others.

The unfertilized end of the field produced tobacco of no commercial value. Hence at the time of harvest 20 plants from each treatment, from fertilized and unfertilized ends, were weighed and their green weight serves as an indicator of possible fertilizer value of the various solutions.

The results, expressed on a relative basis, were as follows:

$\begin{array}{crr}\text { Check } & & 100.0 \\ \text { Solution }^{1} & \text { No. } 1 & 92.4 \\ \text { “ } & \text { No. } 2 & 100.0 \\ \text { “ } & \text { No. } 3 & 101.9 \\ \text { “ } & \text { No. } 4 & 104.0 \\ \text { “ } & \text { No. } 5 & 97.3\end{array}$

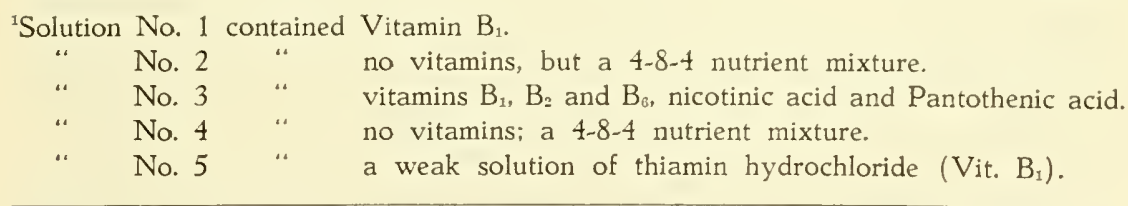

Thus, observations on growth checked with actual weights; solutions No. 3 and No. 4 produced slightly better growth.

Later on, the fertilized end of the field was harvested in the regular way. After proper curing the crop was sorted. Data obtained at that time are recorded in Table 26. Since the experiment was carried out on a small scale, single rows for each treatment, the results cannot serve as a basis for definite conclusions. They suggest, however, that a rather weak nutrient solution added to the water at time of planting is more valuable than attempting to promote growth of young tobacco plants with vitamins and other substances claimed to promote growth. 
Table 26. Yield and Grading Records of Tobacco Grown With Starter Solutions (Commercial). Crop of 1940.

\begin{tabular}{|c|c|c|c|c|c|c|c|c|}
\hline \multirow{2}{*}{ Treatment } & \multirow{2}{*}{$\begin{array}{c}\text { Yield } \\
\text { per } \\
\text { acre }\end{array}$} & \multicolumn{6}{|c|}{ Percentage of grades } & \multirow{2}{*}{ Grade index } \\
\hline & & LS & $\mathrm{s}$ & $\mathrm{L}$ & $\mathrm{D}$ & $\mathrm{F}$ & B & \\
\hline None & 1406 & 11 & 7 & 一 & 50 & 21 & 11 & .219 \\
\hline Solution No. 1 & 1350 & 9 & 9 & 18 & 30 & 16 & 18 & .229 \\
\hline “ No. 2 & 1547 & 17 & 12 & 33 & 17 & 13 & 8 & .292 \\
\hline No. 3 & 1625 & 25 & 9 & 36 & 14 & 12 & 4 & .329 \\
\hline No. 4 & 1714 & 23 & 8 & 33 & 18 & 13 & 5 & .315 \\
\hline No. 5 & 1453 & 16 & 4 & 29 & 25 & 17 & 9 & .271 \\
\hline
\end{tabular}

\section{IRRIGATION OF HAVANA SEED TOBACCO IN 1940}

The season of 1940 was not an ideal one for irrigation trials since there was more than enough rain until the latter part of July. The rainfall for August, however, was only about half of normal (see Table 1) and tobacco began to suffer from drouth when it had just reached the topping stage. This was particularly true on the light, sandy lands. One such area (Field VII) offered a good opportunity to continue the irrigation experiments which are repeated here each year that is considered dry enough to warrant application of additional water.

The plots were irrigated on August 2 and again on August 9 by running water between the rows in sufficient quantity to equal a rain of approximately one and one-half inches (for complete de scription of method, see Sta. Bul. 391). Previous trials on such land have shown us that irrigation at this rate may leach away the nitrogen and cause starvation of the plants. This danger was especially feared in 1940 because the early, heavy rains had already depleted the nitrogen supply. To overcome this, nitrate of soda was sprinkled in the water, while it was still standing between the rows, at the rate of 200 pounds at the first irrigation and 150 pounds the second time. This dissolved immediately and soaked down into the soil around the roots. Other rows were irrigated without the addition of nitrate, and adjacent parts of the field received neither water nor nitrate.

The irrigated plots picked up and gave a much more leafy appearance throughout the rest of the season. Those which had not received extra nitrate, however, were distinctly paler in color at time of harvest. This field was harvested August 15, the tobacco cured in the regular manner and sorted commercially in December. The yield and grading records are shown in Table 27.

The results, as shown in this table, are quite in line with those from previous tests as described in our report for 1936 (Bul. 391, page 67).

The addition of water alone to a leachy soil of this type caused a small reduction in the yield and grading of the tobacco.

When nitrate of soda was sprinkled in the water at each irrigation, the yield was increased by 12.4 percent and the grade index by 
17.2 percent. Representing the value of the non-irrigated part by the figure 100, the irrigated part with nitrate added would have a value of 131.7, or an increase of 31.7 percent. That the improvement was due partly to increase in length of leaf is indicated by the lower percentage of short seconds, short darks and fillers. The higher percentage of light wrappers shows that there was an improvement in quality in addition to size.

The increase in poundage this year was considerably larger than in the crop of 1936 (Bul. 391), due probably to the greater depletion of nitrate by early, heavy rains.

Another difference between this trial and those of 1936 was that nitrate of soda was used instead of nitrate of lime. The results do not indicate any advantage of the latter.

All results to date seem to warrant the conclusion that both the yield and quality may be improved in a dry year by irrigation if nitrate is added at time of irrigation to replace that which is leached and to provide for further growth of the leaves. Irrigation alone, without nitrate, may do more harm than good on a light, sandy field.

Table 27. Yield and SoRting Records of Irrigation Plots.

CROP OF 1940.

\begin{tabular}{|c|c|c|c|c|c|c|c|c|c|c|c|}
\hline \multirow{2}{*}{ Treatment } & \multirow{2}{*}{$\begin{array}{l}\text { Yield } \\
\text { per } \\
\text { acre }\end{array}$} & \multicolumn{8}{|c|}{ Percentage of grades } & \multirow{2}{*}{ Grade index } & \multirow{2}{*}{$\begin{array}{l}\text { Relative } \\
\text { crop } \\
\text { value }\end{array}$} \\
\hline & & $\mathrm{L}$ & M & LS & SS & LD & DS & $\mathrm{F}$ & $\mathrm{B}$ & & \\
\hline $\begin{array}{l}\text { No irrigation or } \\
\text { extra fertilizer }\end{array}$ & 1624 & 7 & 7 & 23 & 11 & 27 & 12 & 11 & 2 & .401 & 100. \\
\hline Irrigated only & 1599 & 5 & 3 & 28 & 11 & 28 & 11 & 13 & 1 & .389 & 95.51 \\
\hline $\begin{array}{l}\text { Irrigated and } \\
\text { nitrate applied }\end{array}$ & 1825 & 13 & 7 & 27 & 7 & 32 & 5 & 8 & 1 & .470 & 131.71 \\
\hline
\end{tabular}

\section{TOBACCO DISEASES IN 1940}

The crop of 1940 was relatively free from diseases except for downy mildew. The total damage from other diseases was practically negligible, although most of the common diseases were observed in some section of the Valley.

\section{Downy Mildew (Blue Mold)}

During the late winter and early spring, a campaign was inaugurated to persuade as many growers as possible to take precautions against mildew and to use benzol or paradichlorobenzene (designated in the remainder of this article as PDB) to destroy it as soon as it appeared - or as a preventive before it appeared - in the beds. Growers meetings were held in the principal tobacco centers and the disease discussed and methods of control explained. Bulletins and letters containing the same information were sent to all growers. 
The daily papers also gave publicity to the campaign. Since the beds are the principal source of infection, it was hoped that by elimination of mildew in the beds we could prevent a field epidemic such as that which caused serious losses the previous year.

Despite the flood of warnings, however, many growers, especially those planting outside tobacco, made little or no effort to keep. their seedbeds free of mildew. The first infections were reported on May 22, somewhat later than in other years. Within a few days it was reported from every section of the Valley. The entire seedbed period was cold and rainy, weather very favorable to mildew. Some beds were completely ruined and abandoned but this was unusual. In most cases the plants were not killed; after all the large leaves died, the bud leaves grew out and the damage consisted of a delay of a week or more in setting. Since the season as a whole was already 10 days to two weeks behind normal, such a delay was more harmful than it would have been ordinarily. Many crops would have escaped the late August frost if they had been set earlier. Plants became scarce as growers began to purchase from neighbors. and the price went up. At the height of the epidemic, no Broadleaf plants could be bought, but the usual acreage was finally set although quite late. Since all of the shade growers used benzol or PDB in the beds, there was no shortage of shade plants. Not all of the shade growers, however, escaped mildew completely in the beds, since some relaxed their vigilance and were caught in the late in fection.

Although both benzol and PDB were used, more growers used the latter than the former because of its greater convenience. This gave us abundant opportunity to compare results under farm conditions. There were many failures to control with PDB while benzol was effective in almost all cases; the few failures were due to loose beds or use of too little material. As we have frequently pointed. out in previous reports, the effectiveness of PDB is quite dependent on temperature. It cannot be used successfully in cold weather with temperatures in the beds below $45^{\circ}$ F. during the night. Such temperatures prevailed during a large part of the seedbed period of 1940 . The lack of control by PDB is, therefore, not surprising. At higher temperatures it is just as effective as benzol.

The experience of one shade firm, however, with PDB, should be recorded and may furnish a clue to control with this material. The company did not wait until mildew appeared, but began using PDB every second or third night in the beds as soon as the plants. were well out of the ground. Although their farms are widely distributed over the Connecticut Valley in this State and in Massachusetts and the beds had every chance for inoculation, they reported that the beds remained remarkably free from mildew. Possibly by such constant and early use of the crystals, they "nipped in the bud" the primary infections - occasional warm nights could make this. possible - and thus prevented subsequent spread.

On the other two types of tobacco, mildew was just as wide- 
spread and severe in 1940 as in previous years and our eradication campaign failed to accomplish the hoped-for results.

The months of June and early July continued subnormally cold and rainy with the result that mildew became prevalent in the shade fields. The infection damaged the lower leaves almost as seriously as the epidemic of 1939. At time of harvesting, the badly spotted leaves were left in the fields and many more that reached the curing sheds were "graded down" during the sorting. Mildew spots were also commonly seen in Havana Seed fields but loss from this source was small as compared with losses of the shade growers. No damage to Broadleaf in the field was reported.

Although the seedbeds are undoubtedly the main sources of field infection, there was good evidence this year that a part of the field infection originates in the field itself. It is well established that the winter spores of the mildew fungus are capable of living over from one season to the next in the soil and when they germinate in the spring they start the next year's epidemic. This may occur in the field soil just as well as in the soil of the seedbed. But, as a rule, infection in the field, originating from winter spores, hardly has time to build up and spread seriously before hot weather checks the epidemic. Conditions in the bed, however, are ideal for such a build-up. This year the long duration of cold, wet weather, after the plants were set, seems to have been favorable to a field build-up. One grower set two adjacent shade tents in 1940, one of which had sheltered tobacco seriously diseased in 1939. The other had not been set to shade tobacco in 1939. This year mildew again became quite destructive in the old field but was very little in evidence in the new field although both fields were set at the same time with plants from the same beds. This is only one of a number of cases in which mildew appeared in the same parts of the fields in 1940 where it had been prevalent in 1939. One can only conclude from these repeated observations that the fungus is capable of wintering over in the soil and starting an epidemic the following year among plants that are perfectly healthy when set. It is hoped and believed, however, that epidemics from this source will not be serious during normally warm summers. Therefore, since no practical method of stopping mildew, when it has once become established in the field, has been found, it appears that our best hope still lies in trying to keep the beds as free as possible from disease.

Another possible method of control should be mentioned in this connection although it has not been worked out on a practical scale. This might be called the "vaccination" method. It is well known that a plant that has had mildew and recovered, thereafter becomes highly resistant to the disease. Growers frequently comment on the recovery of badly diseased beds and find that fields set from such beds are apt to remain free from mildew. If a method of uniformly infecting all the plants of a bed without killing them could be perfected, there would be little danger of field trouble by setting these plants after they recovered. This method would necessarily involve 
some delay in setting, since plants set while still in the early stages of mildew, before recovery, do not live well when transplanted to the field.

Mildew has been reported from other tobacco sections as occurring on suckers in the fall, but the writer has never been able to find such infections here. On September 17 of this year, however, the disease was found in abundance on some "volunteer" shade plants in East Hartford, ranging in size from a few inches to a foot high. Such fall infections as this might play a role in the wintering over of mildew.

\section{Bed Rots}

Bed rots were not more prevalent than usual, despite the cool, wet season that would naturally favor their development. Those investigated were caused mostly by Pythium aphanidermatum and a few by Rhizoctonia. Other types were not seen. In some instances both bed rot and mildew were working in the same bed with devastating results.

\section{Wildfire}

During the whole spring and summer only three cases of wildfire were seen, none of them in the field. This disease has sunk into such insignificance during the last 12 or more years that it does not appear likely to become an important factor again in tobacco production.

\section{Blackfire}

During the latter part of May blackfire became prevalent in some of the seedbeds. The numerous black spots on the leaves caused considerable alarm among the growers who had never seen this unusual disease. The plants were not killed or seriously damaged and made a normal growth when set in the field. Only negligible field infection was observed on mature plants in some places.

\section{Rootrots}

Rootrots were not troublesome during the season. A few cases of black rootrot were diagnosed, but the disease had affected only relatively small parts of fields.

\section{Mosaic}

The loss from mosaic, or calico, was probably only a fraction of 1 percent, less than the usual amount.

In previous reports we have discussed a project in which we are attempting to develop a strain of Broadleaf that is immune or highly resistant to mosaic. This was started several years ago with a cross between John Williams Broadleaf and Ambelema, a South 
American type that is immune. The hybrid was then back-crossed on Broadleaf. A quarter of an acre of two strains selected from this progeny was grown in 1940 and, although plants were inoculated often during the summer, they developed no symptoms of mosaic, except for occasional dead spots that appeared on the lower leaves of some plants when they became mature.

From a practical standpoint these strains are quite satisfactory as far as resistance is concerned, but they fall short in quality when harvested and sorted. It will be necessary to back-cross again and make further selections to obtain better characteristics of Connecticut Broadleaf.

\section{An August Frost}

On August 25 the temperature dropped below the freezing point in many places, particularly in the north tier of towns in the State. A great deal of damage resulted because more than the usual proportion of the crop, started late in the spring, was still in the field. Injury was quite irregular in its distribution even in the same neighborhood. It is difficult to explain how the frost missed some fields and struck others badly. Frequently the younger plants were less affected than mature plants. Not many were completely ruined since the damage was confined to the upper leaves. After a few days, large areas of the affected leaves died and bleached out. These dead areas cracked and left large holes, making such leaves worthless. On the other hand, when the crops were harvested immediately after the frost, the frosted spots remained green and failed to cure. Buyers were afraid to purchase such crops since it was hard to judge how well they sort out and ferment. Even unaffected crops in a frosted neighborhood suffered in price from suspicion.

Most growers with whom we have talked cannot remember another year when frost damaged tobacco in August.

\section{LUMARITH, A SUBSTITUTE FOR GLASS IN THE SEEDBED SASH}

Glass in the seedbed sash is subject to some objections. It is heavy and easily broken, thus making the work of handling the sash hard and awkward. Twisting of the sash and other accidents break many panes which must be replaced at considerable cost of labor and material. Heat escapes not only through the broken panes but, in even greater amount, between and around the unbroken ones.

Various materials which would overcome some of these objections have been offered on the market and tested here and elsewhere (Conn. Sta. Bul. 311: 273). Some of them have found a limited use with tobacco growers. This season another one was tried on the Experiment Station beds which may be found more suitable than those previously tested. This material, called "Lumarith", is a transparent plastic made from cellulose acetate, very light, pliable and strong. It is not affected by changes in temperature but stretches when wet. This latter property is an advantage since lumarith can 
be attached to the frames in its stretched condition and become quite tight and smooth on drying. Such a seedbed frame can be handled roughly without injury. It is light, weighing less than half as much as a glass sash and can be removed or replaced on the bed easily by one man. Two men can carry four or more frames at a time. Lumarith is also said to admit the ultra violet rays of light which are filtered out by ordinary glass and from this standpoint is claimed to be more beneficial to plants. Lumarith sash would keep the heat in the beds more effectively than the ordinary sash used here, since there can be no air leakage through them.

In order to compare the development of tobacco plants under lumarith with those under glass, three sections of our seedbeds, each 15 feet long and 6 feet wide, were separated from the remainder of the beds by cross partitions. Each of these sections was covered with five lumarith sash throughout the seedbed period. The development of the plants under these and the adjacent ordinary glass sash was watched daily. No accurate measuring or weighing of the plants was attempted or thought necessary. The development under lumarith was satisfactory and at least as good as that under glass. At times it appeared better under lumarith but there did not appear to be any great differences among plants from the different parts of the bed at setting time. At least we may conclude that there are no disadvantages to the plants in substituting lumarith for glass. That the lumarith makes a tighter covering than glass is indicated by the constant accumulation of drops of water on the underside. Sometimes this is observed under glass but is much more pronounced with the lumarith.

\section{STUDIES ON BLACK TOBACCO}

\section{S. B. LECOMPTE, JR.}

In the Connecticut Valley tobacco industry, "black" tobacco is the term applied to a dull, matte-surfaced, low quality leaf that cures very dark brown with a blue-gray or purple-gray hue. The ash is often muddy in color. In the curing of Shade, Havana Seed, and Broadleaf tobacco, black leaves are known to occur; they are observed most frequently, however, in the shade variety. Black tobacco has low value because of its undesirable qualities; it is worthless for fine cigar manufacture and is a considerable loss to the grower.

Black tobacco should not be confused with the natural dark grades that are made in sorting a crop of any type of tobacco. Such dark grades consist of leaves which come from the upper part of the plant. The black tobacco discussed here very commonly comes from the lower part of the plant, a region of the stalk where normally the leaves are of the lightest color. Packers of shade tobacco usually put these leaves in a separate grade often designated as "blue-black".

To our knowledge, no information on the causes and remedies of Connecticut Valley black tobacco has been published. This report 
describes preliminary studies of the problem conducted at the Tobacco Substation.

The present facts indicate that the problem may be attacked from the nutritional or agronomic point of view. Disease organisms seem to play no part in producing black tobacco. No special microorganism or fungus has been found associated with this type of leaf. Although the dark pigments first become evident in the curing process, we are led to suspect that the trouble is due to unfavorable or pathological internal conditions of the leaf instead of the external influences of the atmosphere in the curing shed. Good, light colored leaves are often found cured on the same lath with black leaves and it is not unreasonable to suppose that curing conditions would have affected in a similar way all the leaves in that restricted space, had foliar internal conditions been comparable at picking time.

That blackness in cured tobacco bears a relation to soil conditions seems to be the experience of growers. Black tobacco is seldom found on some farms; on others it is regularly and distressingly abundant. It is said to be more plentiful in some years than in others, and is often characteristic of definite plots or patches of ground within otherwise good fields. It may be scattered all through a good light crop. However, a difference between potentially light and potentially black tobacco cannot be observed in the field. Not until curing is partially complete is the grower able to distinguish the two types.

\section{Chemical Examination of Plant Material}

Through the courtesy of growers and dealers, numerous samples of black tobacco have been collected from widely scattered localities in the Connecticut Valley. At the same time, for the sake of comparison, there have been collected samples (usually whole hands, about 40 entire leaves) of good, light-colored tobacco from the same farms or even from the same plots which produced the black samples. Some early, rather complete analyses showed that the most noticeable chemical difference between the light and black leaves was in the percentage content of manganese and iron. The other components (total nitrogen, ammonia, glutamine, asparagine, phosphorus, potassium, calcium and magnesium) showed no consistent differences between black and light tobacco. In this preliminary chemical examination, therefore, tobacco samples have been analyzed principally for the ash constituents, manganese and iron. ${ }^{1}$

${ }^{1}$ Samples were oven-dried, pulverized in a porcelain mortar with a porcelain pestle, sifted through copper window screen to remove coarse vascular tissue, and preserved in well-stoppered bottles. Powdered samples were oven-dried just before weighing out portions for ashing. By means of a photo-electric colorimeter, the concentrations of iron and manganese were ascertained with the thiocyanate and periodate methods, respectively. 


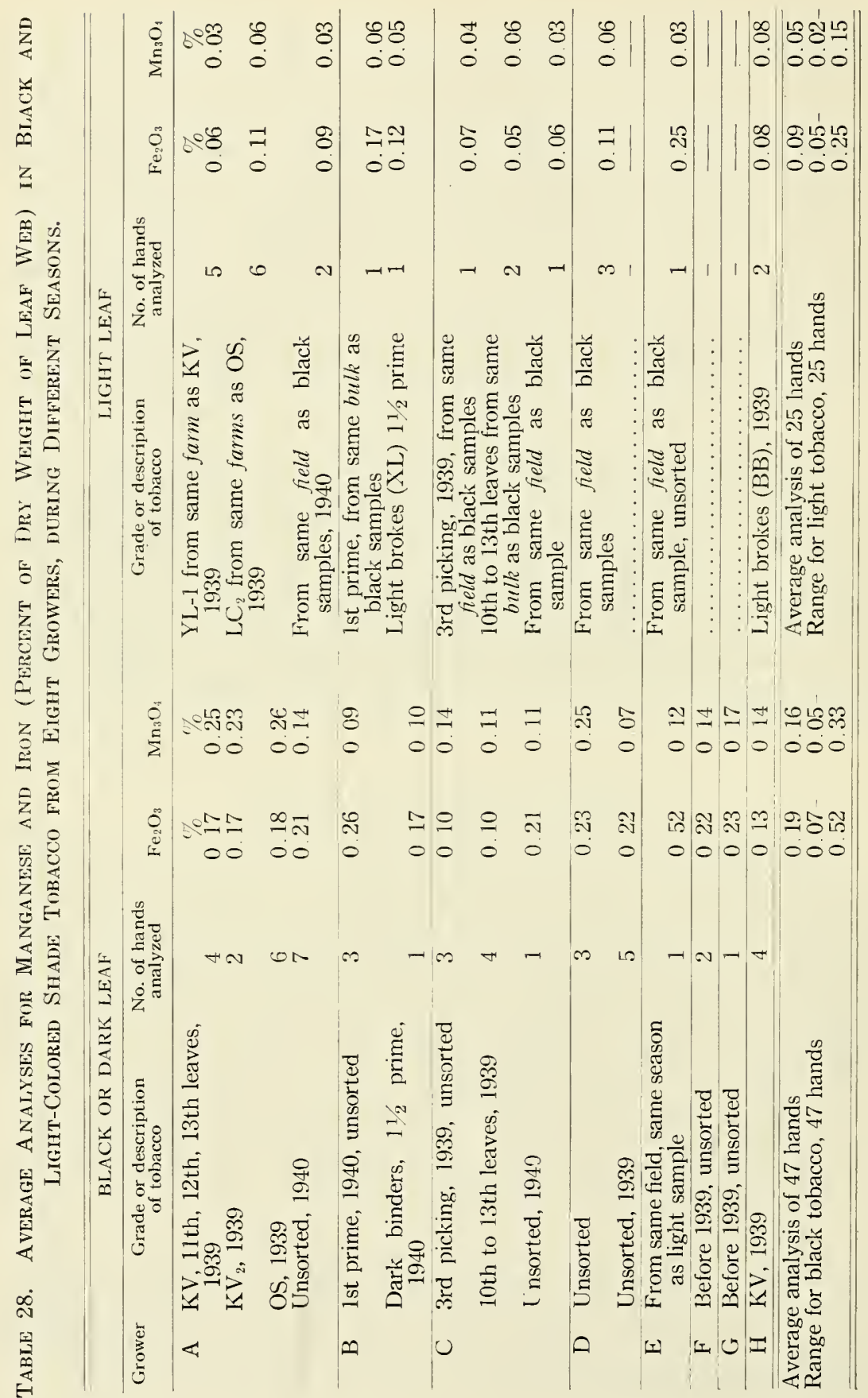


Table 28 presents for comparison concentrations of manganese and iron of black and light hands of shade leaf from eight growers. The samples represent different seasons. It is apparent that the black tobaccos of any one grower usually contained a greater percentage of iron and manganese than did his light tobaccos. Neither the light nor dark leaf type was identified with a characteristic content of the metals studied. The average test of 47 black hands was 0.19 percent $\mathrm{Fe}_{2} \mathrm{O}_{3}$ and 0.16 percent $\mathrm{Mn}_{3} \mathrm{O}_{4}$ on the basis of dry weight of leaf web. For the black hands represented in Table 28, $\mathrm{Fe}_{2} \mathrm{O}_{3}$ content ranged from 0.07 percent to 0.52 precent and $\mathrm{Mn}_{3} \mathrm{O}_{4}$ content ranged from 0.05 percent to 0.33 percent. The average test of 25 light hands was 0.09 percent $\mathrm{Fe}_{2} \mathrm{O}_{3}$ and 0.05 percent $\mathrm{Mn}_{3} \mathrm{O}_{4}$. The light hands of Table 28 ranged from 0.05 percent to 0.25 percent $\mathrm{Fe}_{2} \mathrm{O}_{3}$ and from 0.02 percent to 0.15 percent $\mathrm{Mn}_{3} \mathrm{O}_{4}$ content.

Iron and manganese in relation to shade sorting. Samples of first prime (first, second, third leaves) black tobacco from two farms of Grower f were sorted into three color-grades: lighter, mediumdark, very dark. Results of analysis are presented in Table 29. The trend to higher percentages of $\mathrm{Fe}_{2} \mathrm{O}_{3}$ and $\mathrm{Mn}_{3} \mathrm{O}_{4}$ in the darker grades is conspicuous.

Table 29. Iron and Manganese in Relation to Color-Grade of Blach, First Prine Silade Leaf from Two Faris, 1940. Crop.

\begin{tabular}{|c|c|c|c|c|}
\hline \multirow[b]{2}{*}{ Color-grade } & \multicolumn{2}{|c|}{ Farm I } & \multicolumn{2}{|c|}{ Farm 2} \\
\hline & $\begin{array}{c}\mathrm{Fe}_{2} \mathrm{O}_{3} \\
\%\end{array}$ & $\begin{array}{c}\mathrm{Mn}_{3} \mathrm{O}_{4} \\
\%\end{array}$ & $\begin{array}{c}\mathrm{Fe}_{2} \mathrm{O}_{3} \\
\%\end{array}$ & $\begin{array}{c}\mathrm{Mn}_{3} \mathrm{O}_{4} \\
\%\end{array}$ \\
\hline Lighter & 0.27 & 0.07 & 0.21 & 0.04 \\
\hline Medium-dark & 0.44 & 0.12 & 0.54 & 0.14 \\
\hline Very dark & 0.38 & 0.13 & 0.41 & 0.16 \\
\hline
\end{tabular}

Grower J also submitted representative unsorted hands of tobacco from each picking (1940 crop) of farms 1 and 2. A large portion of the harvest from farms 1 and 2 was black. The hands were sorted severally at our laboratory into three color-grades: lighter, medium, and dark. The color differences between the grades of the third and fourth pickings were almost indistinguishable. There was extreme color contrast between blacks of first picking and lights of the third and fourth pickings. Analyses for iron and manganese by grades are presented in Table 30. 
Table 30. Iron and Manganese in Relation to Color-Grade and Order of Picking in Shade Leaf from Two Farms, Crop of 1940.

\begin{tabular}{|c|c|c|c|c|}
\hline \multirow[b]{2}{*}{ Color-grade } & \multicolumn{2}{|c|}{ Farm I } & \multicolumn{2}{|c|}{ Farm 2} \\
\hline & $\begin{array}{c}\mathrm{Fe}_{2} \mathrm{O}_{3} \\
\%\end{array}$ & $\begin{array}{c}\mathrm{Mn}_{3} \mathrm{O}_{4} \\
\%\end{array}$ & $\begin{array}{c}\mathrm{Fe}_{2} \mathrm{O}_{3} \\
\%\end{array}$ & $\begin{array}{c}\mathrm{Mn}_{3} \mathrm{O}_{4} \\
\%\end{array}$ \\
\hline $\begin{array}{l}\text { Lighter } \\
\text { Medium } \\
\text { Dark }\end{array}$ & $\begin{array}{l}\text { Fourth picking, } \\
0.26 \\
0.35 \\
0.25\end{array}$ & $\begin{array}{l}\text { 10th, } 11 \text { th, } 12 \text { th leaves }{ }^{1} \\
0.04 \\
0.05 \\
0.07\end{array}$ & $\begin{array}{l}\cdots \cdots \\
\cdots \cdots \\
\cdots \cdots\end{array}$ & $\begin{array}{l}\cdots \cdots \\
\cdots \cdots \\
\cdots \cdots\end{array}$ \\
\hline $\begin{array}{l}\text { Lighter } \\
\text { Medium } \\
\text { Dark }\end{array}$ & $\begin{array}{c}\text { Third picking, } \\
0.25 \\
0.17 \\
0.19\end{array}$ & $\begin{array}{l}\text { 7th, 8th, 9th leaves } \\
0.06 \\
0.07 \\
0.11\end{array}$ & $\begin{array}{l}0.09 \\
0.11 \\
0.12\end{array}$ & $\begin{array}{l}0.01 \\
0.02 \\
0.01\end{array}$ \\
\hline $\begin{array}{l}\text { Lighter } \\
\text { Medium-dark } \\
\text { Very black }\end{array}$ & $\begin{array}{l}\text { Second picking } \\
0.20 \\
0.25 \\
0.26\end{array}$ & $\begin{array}{l}\text {, 4th, 5th, 6th leaves } \\
0.05 \\
0.09 \\
0.15\end{array}$ & $\begin{array}{l}0.27 \\
0.23 \\
0.32\end{array}$ & $\begin{array}{l}0.07 \\
0.06 \\
0.10\end{array}$ \\
\hline $\begin{array}{l}\text { Lighter } \\
\text { Medium-dark } \\
\text { Very black }\end{array}$ & $\begin{array}{c}\text { First picking, } \\
0.43 \\
0.44 \\
0.50\end{array}$ & $\begin{array}{l}\text { 1st, } 2 \text { nd, 3rd leaves } \\
0.04 \\
0.12 \\
0.14\end{array}$ & $\begin{array}{l}0.26 \\
0.33 \\
0.38\end{array}$ & $\begin{array}{l}0.03 \\
0.09 \\
0.11\end{array}$ \\
\hline
\end{tabular}

${ }^{1}$ Leaves numbered serially, counting from base of plant.

The data show that the darker and lower leaves of the first and second pickings generally contained more iron and manganese than the lighter leaves taken from the upper parts of the plant in the third and fourth pickings. The demonstration is clear that visual selection nearly succeeded in establishing a series of grades which showed progressively increased concentrations of iron and manganese. There follows another example of such gradation in professionally sorted leaves from a single field of Grower A, 1940 crop. Table 31 shows that as the leaves were darker they were also richer in both iron and manganese.

Table 31. Iron and Manganese in Relation to Grade of Dark Shade Leaf Fron a Single Field, 1940 Crop.

\begin{tabular}{lcc}
\hline Dark grade & $\begin{array}{c}\mathrm{Fe}_{2} \mathrm{O}_{3} \\
\%\end{array}$ & $\begin{array}{c}\mathrm{Mn}_{3} \mathrm{O}_{4} \\
\%\end{array}$ \\
\hline V1 & 0.14 & 0.07 \\
V2 & 0.17 & 0.08 \\
KV1 & 0.19 & 0.14 \\
"Blue Black" & 0.25 & 0.19 \\
\hline
\end{tabular}

The highest percentage of $\mathrm{Fe}_{2} \mathrm{O}_{3}$ noted in black shade leaf is 0.54 percent; the extreme low of $\mathrm{Mn}_{3} \mathrm{O}_{4}$ for light colored shade leaf, 0.01 percent, see above tables, 29 and 30 .

Iron and manganese in Havana Seed tobacco. Leaves from several darkly cured plants grown on one field of Havana Seed and leaves from several light colored plants grown on an adjacent field compared as follows: 
Havana Seed Tobacco, Unfermented

\begin{tabular}{ccccc}
\hline$\% \mathrm{Fe}_{2} \mathrm{O}_{3}$ & Black & $\% \mathrm{Mn}_{3} \mathrm{O}_{4}$ & $\% \mathrm{Fe}_{2} \mathrm{O}_{3}$ & Light \\
\hline 0.05 & 0.19 & 0.17 & $\mathrm{Mn}_{3} \mathrm{O}_{4}$ \\
\hline
\end{tabular}

In the case just noted, the blackness agreed with the manganese content but not with the iron content. Soil tests of the two fields after the 1940 harvest compare as follows:

\begin{tabular}{lccccccc}
\hline $\begin{array}{l}\text { Field of } \\
\text { Havana Seed }\end{array}$ & $\mathrm{pH}$ & $\begin{array}{c}\text { Nitrate } \\
\text { nitrogen }\end{array}$ & $\begin{array}{l}\text { Ammonia } \\
\text { nitrogen }\end{array}$ & Phosphorus & $\begin{array}{c}\text { Potas- } \\
\text { sium }\end{array}$ & $\begin{array}{l}\text { Cal- } \\
\text { cium }\end{array}$ & $\begin{array}{c}\text { Magne- } \\
\text { sium }\end{array}$ \\
\hline Black & 5.09 & High & Low & Low & $\begin{array}{l}\text { Extra } \\
\text { high }\end{array}$ & Low & High \\
Light & 5.20 & $\begin{array}{c}\text { Medium } \\
\text { high }\end{array}$ & Low & Medium & $\begin{array}{l}\text { Extra } \\
\text { high }\end{array}$ & High & High \\
\hline \hline
\end{tabular}

The above tabulation shows that the field producing black Havana Seed tobacco tested significantly lower than the field of light tobacco in $\mathrm{pH}$, phosphorous and calcium supply.

Iron and manganese in Broadleaf tobacco. Middle leaves of 14 black (very dark, dull red-brown) plants grown on one field of Broadleaf, and middle leaves of 12 good, light colored plants grown on an adjacent field compared as follows:

BroadLEAF TOBACCO, UNFERMENTED

\begin{tabular}{lcclcc}
\hline & \multicolumn{1}{c}{ Black } & & & $\begin{array}{c}\text { Light } \\
\% \mathrm{~F}_{2} \mathrm{O}_{3}\end{array}$ & $\% \mathrm{Mn}_{3} \mathrm{O}_{3}$ \\
\hline $\begin{array}{l}8 \text { very dark, red- } \\
\text { brown leaves }\end{array}$ & 0.42 & 0.36 & $\begin{array}{l}6 \text { light, red-brown } \\
\text { leaves }\end{array}$ & 0.21 & 0.02 \\
$\begin{array}{l}6 \text { very dark, red- } \\
\text { brown leaves }\end{array}$ & 0.18 & 0.56 & $\begin{array}{l}6 \text { medium-dark, red- } \\
\text { brown leaves }\end{array}$ & 0.27 \\
\hline \hline
\end{tabular}

The dark Broadleaf was richer in manganese than the light tobacco from an adjacent field.

Tests of the active constituents of the soil where the dark plants grew are as follows:

\begin{tabular}{lcccccccc}
\hline $\mathrm{pH}$ & $\begin{array}{c}\text { Nitrate } \\
\text { nitrogen }\end{array}$ & $\begin{array}{c}\text { Ammonia } \\
\text { nitrogen }\end{array}$ & $\begin{array}{c}\text { Phos- } \\
\text { phorus }\end{array}$ & $\begin{array}{c}\text { Potas- } \\
\text { sium }\end{array}$ & $\begin{array}{c}\text { Cal- } \\
\text { cium }\end{array}$ & $\begin{array}{c}\text { Magne- } \\
\text { sium }\end{array}$ & Aluminum Manganese \\
\hline 3.89 & $\begin{array}{c}\text { Very } \\
\text { high }\end{array}$ & Low & $\begin{array}{c}\text { Medium } \\
\text { high }\end{array}$ & $\begin{array}{c}\text { Extra } \\
\text { high }\end{array}$ & Low & Medium & High & $\begin{array}{c}\text { Extra } \\
\text { high }\end{array}$ \\
\hline
\end{tabular}

Unfortunately test data are not available for the soil which produced the lighter plants. Notable, however, are the extreme acidity, the low calcium, high aluminum and extra high active manganese shown above. The dark leaves produced on this soil gave the highest tis- 
sue test for manganese $\left(0.56\right.$ percent $\left.\mathrm{Mn}_{3} \mathrm{O}_{4}\right)$ noted in this report. Half a ton of this soil has been brought to the laboratory for experimental culture of tobacco.

\section{Soil Tests in Relation to Black and Light Shade Tobacco}

For 58 fields that produced good light leaf and for 26 fields that produced black tobacco, soil test data have been assembled from the files of this Substation and are presented in Table 32. All soil samples were taken after the harvest of either 1939 or 1940. The frequency of occurrence of a test is written as a percentage of the total number of fields examined.

We are not justified in drawing any strong inference from the data in Table 32 regarding the effect of the soil on the crops harvested. However, there is a tendency of fields which produced black tobacco to have a lower average $\mathrm{pH}$, a lower calcium and phosphorus supply than the fields which grew light tobacco. This tendency appears to agree with the well-known conditions favorable to excessive absorption by plants of aluminum, iron, manganese, and zinc from soils containing these metals in sufficient quantities.

\section{Conclusions}

It is tentatively suggested from the evidence presented above that black tobaccos may be produced on soils excessively acid with low supplies of calcium and phosphorus. Black shade leaf from any one farm generally tested higher than light shade leaf from the same farm in contents of iron and manganese.

On the basis of dry weight, black shade leaf averaged about 0.19 percent $\mathrm{Fe}_{2} \mathrm{O}_{3}$ (range from 0.07 percent to 0.54 percent), and about 0.16 percent $\mathrm{Mn}_{3} \mathrm{O}_{4}$ (range from 0.05 percent to 0.33 percent). Light shade leaf averaged about 0.09 percent $\mathrm{Fe}_{2} \mathrm{O}_{3}$ (range from 0.05 percent to 0.25 percent) and about 0.05 percent $\mathrm{Mn}_{3} \mathrm{O}_{4}$ (range from 0.01 percent to 0.15 percent).

Gradation in color of leaves from light to black from the same fields was accompanied by gradation of iron and manganese contents, the concentration of the metals being almost regularly greater as the colors were darker.

Data from Havana Seed and Broadleaf tobaccos are not numerous, but the few tests for these varieties show higher content of manganese as the tissues were darker. Dark leaves were grown on soil that was unfavorably acid, deficient in calcium, with a low or no more than medium supply of active phosphorus. In two cases, however, the iron content of the light tobaccos was greater than in the dark tobaccos. On a soil which was extremely acid ( $\mathrm{pH}$ 3.89) with low calcium, high active aluminum and extra high active manganese content, dark Broadleaf was grown which showed the highest foliar content of manganese $\left(0.56\right.$ percent $\left.\mathrm{Mn}_{3} \mathrm{O}_{4}\right)$ noted in this study. 


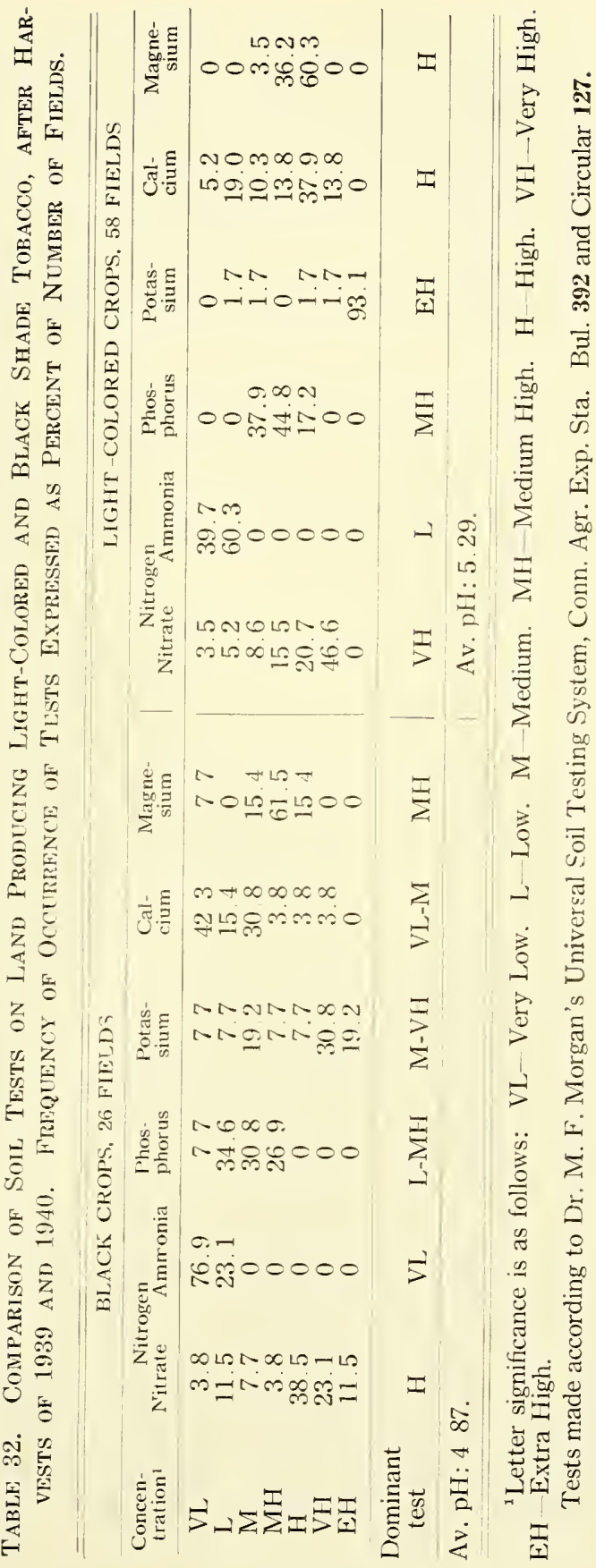


It is obvious that no factor is to be identified at present as the immediate causal link that leads to the type of blackness herein considered. As yet no information has been obtained under this project in regard to pigment and oxidative changes in tobacco curing. The only conclusions justified from this preliminary view of the problem are: (1) that in contrast to light shade leaf there was gen erally greater average content of manganese and iron in the black shade tobacco tested; (2) this was probably occasioned by deficient supply in the soil of calcium and/or active phosphorus, together with an unfavorably acid soil reaction and, (3) these conditions may be no more than circumstances merely attendant to the production of black tobacco.

In view of the relation which this preliminary study indicates between black tobacco and soil acidity, calcium and phosphorus supply, it is suggested that if a soil produces black tobacco and is found to be excessively acid or lacking in adequate calcium or phos phorus, the land should be limed and some carrier of phosphorus added.

\section{INSECT INVESTIGATIONS DURING 1940}

A. W. MorriLL, JR. AND D. S. LACRoIX ${ }^{1}$

Cooperative investigations on the control of the insect pests of tobacco in the Connecticut River Valley which have been conducted since 1936 by the Connecticut Agricultural Experiment Station and the Bureau of Entomology and Plant Quarantine of the United States Department of Agriculture were continued during 1940.

Dust mixtures and sprays were tested on shade-grown and sungrown tobacco in an effort to obtain a simultaneous control of both the potato flea beetle, Epitrix cucumeris, Harr., and the tobacco thrips, Frankliniella fusca Hinds. Naphthalene was tested as a soil fumigant in the control of the eastern field wireworm, Limonius agonus Say. In addition, the field surveys and general observations of insect conditions on tobacco simliar to those made in previous years were continued.

\section{Flea Beetle and Thrips Experiment}

The treatments tested in an attempt to determine a single con trol measure of use against both the potato flea beetle and the tobacco thrips are shown in Table 33.

Because of unusually cold weather, which retarded both the plants and the insect populations, the application of insecticides was not started until July 2. Commencing on that date, the treatments were applied at semi-weekly intervals when the weather permitted until July 30 when the plants had attained a size which made further

${ }^{1}$ Bureau of Entomology and Plant Quarantine, and Conn. Agr. Expt. Sta., respectively. 
Insect Investigations, 1940

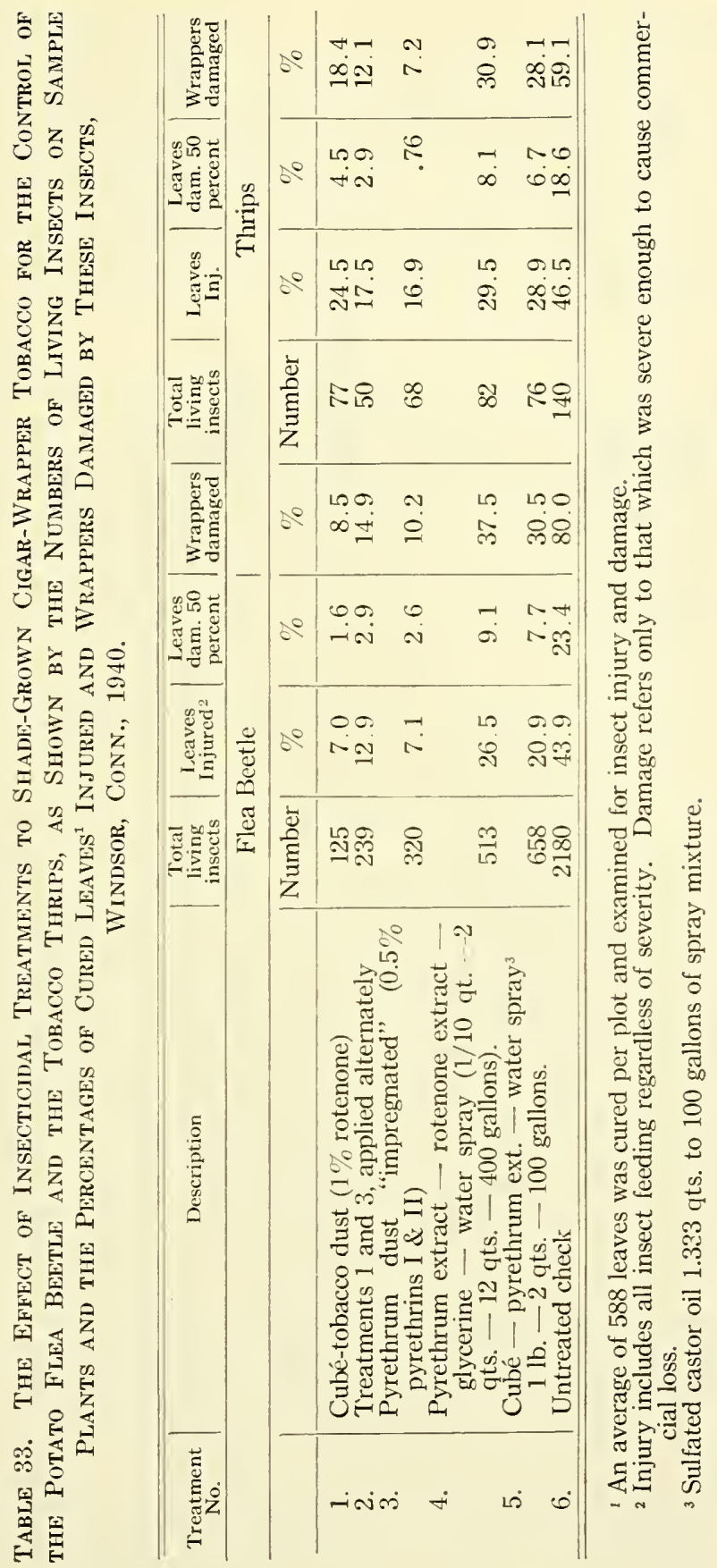


treatment impossible without causing severe mechanical injury to the leaves. A total of seven applications was made with each insecticide. The rate of application of dusts commenced at 6 pounds per acre at the beginning of the season and increased to 12 pounds per acre as the plants grew, while that of the sprays ranged from 30 to 80 gallons per acre. The dusts were applied by rotary hand-operated dusters and the sprays by hand-operated knapsack sprayers. Both dusts and sprays were applied in the early morning, usually before 9 A. M., because this period of the day is freest from disturbing wind movements.

Each treatment, as in 1938 and 1939, was replicated six times on plots arranged in a Latin square. Each plot consisted of one bent of shade-grown tobacco, or one-fortieth acre. In conformity with the methods used in previous experiments, four primings of three leaves each were harvested from each of 10 plants, also chosen at random, in every plot. These leaves were then cured and processed in the usual commercial fashion and were later examined for evidences of insect injury.

Four criteria were used in judging the effectiveness of the treatments: (1) The populations of flea beetles and thrips as sampled at intervals during the growing period of the crop; (2) the percentages of leaves showing evidence of feeding injury by these two insects; (3) the percentage of leaves showing injury severe enough to cause commercial damage to one-half the leaf, and (4) the percentage of the total potential wrappers (four per leaf) showing injury severe enough to damage the value of the wrappers. Counts of live insects were made on 10 sample plants chosen at random in each plot immediately before and again 24 hours after each application of the insecticides. The percentage of leaves injured by feeding was determined by examining all leaves harvested from 10 plants per plot, previously mentioned, after curing and processing were completed. In the case of the last two criteria, injury severe enough to have caused commercial damage if properly located on the leaf, was counted as actual damage even when it was not so located. Thus these two criteria are measurements of the true severity of the injury but overstate the commercial importance of such injury.

The results of the tests, as judged by these four criteria, are given in Table 33 and Figure 4. These data show that the use of the pyrethrum dust gave better control of the thrips than did any of the other treatments. It was also nearly equal to the dust mixture containing 1 percent of rotenone in controlling the flea beetles, and was better in this regard than either of the two sprays. This relationship closely approximates that found in 1939. The cubé dust mixture containing 1 percent of rotenone gave, as before, the best control of flea beetles. All treatments were better than no treatment. 


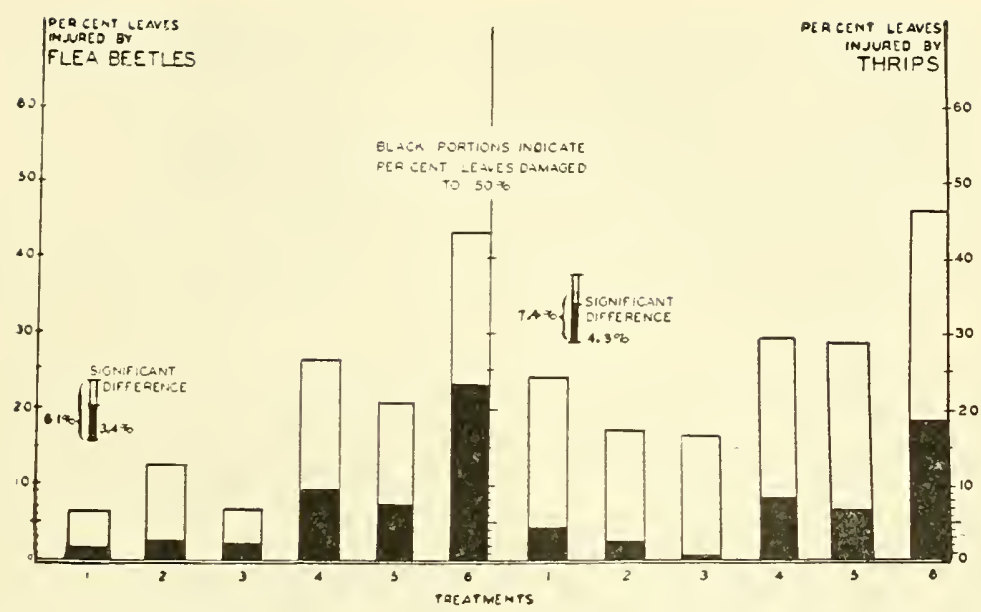

Figure 4. The percentages of tobacco leaves showing injury from feeding by flea beetles and by thrips (whole columns), and the percentages of leaves that had injury amounting to 50 percent damage (black portions), from data in Table 33. Small scale-lines show amounts by which totals must vary to be significantly different. Windsor, Conn., 1940.

\section{Control Experiments on Sun-Grown Tobacco}

A somewhat similar experiment on the control of the tobacco thrips and the potato flea beetle was conducted on plots of sungrown tobacco in Portland, Connecticut. Each treatment was replicated four times on plots one-thirty-third acre in size that were arranged in two randomized blocks. The treatments used consisted of semi-weekly applications of the dusts shown in Table 34 during the period August 1 to August 16. These dusts were applied by means of rotary hand-operated dusters at rates of from 3 pounds to 30 pounds per acre, depending upon plant size. The effectiveness of treatments was determined by counts of living flea beetles and thrips on 10 plants per plot just before and 24 hours after each application. The results from this experiment are given in Table 34 . These data show a trend somewhat similar to that of the results on shade-grown tobacco. With the exception of the cubé dust to which an essential oil stabilizer had been added, both cubé and pyrethrum dusts controlled the flea beetles, and pyrethrum dust gave a degree of control of thrips. The addition of the essential oil stabilizers was not shown to be useful in increasing the efficacy of the dusts.

\section{Wireworm Control Experiments}

On June 13, twelve plots, one-fortieth acre in area (33 by 33 feet) were treated with naphthalene at the rate of 800 pounds per acre, applied in furrows 9 inches deep, approximately 9 inches apart, 


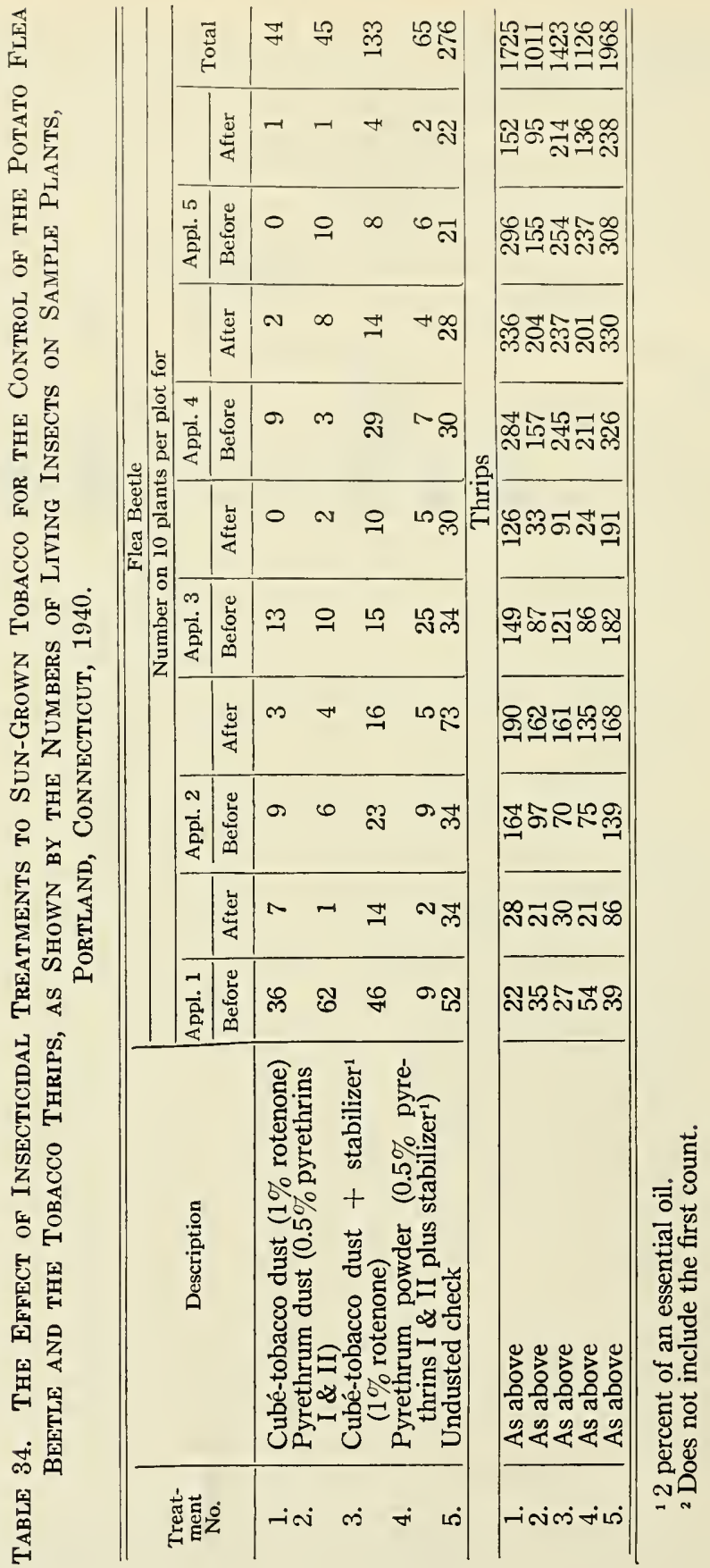


and later harrowed. Twelve similar plots were treated in the same manner with 1,000 pounds of naphthalene per acre, and 12 others were plowed and harrowed but were not treated with naphthalene. The 36 plots were arranged in 12 randomized blocks. The effectiveness of the treatment was determined by counting the numbers of wireworms obtained in sifting the soil from three units of one cubic foot each, located at random in the central portion of each plot. The plots were set with tobacco two days after treatment and no difference could be noted in the vigor of the plants on the treated and untreated plots.

Despite the lateness of the application, low temperatures persisted during the early weeks of the experiment. On June 19 the average reductions in wireworm infestation recorded for the plots treated with 800 pounds of naphthalene, 1,000 pounds of naphthalene, and those receiving no treatment were: 23.7 percent, 25.4 percent and 2.4 percent, respectively. While the reductions in wireworm infestation were significantly greater in the plots treated with naphthalene than in those not treated, the reductions obtained were not sufficient to be of much practical significance to the grower.

\section{Insect Abundance During 1940}

A survey to determine the severity of damage by insects to sungrown tobacco in the Connecticut River Valley was conducted during August, following the method used in previous years. This survey showed that the damage by insect pests was less severe during

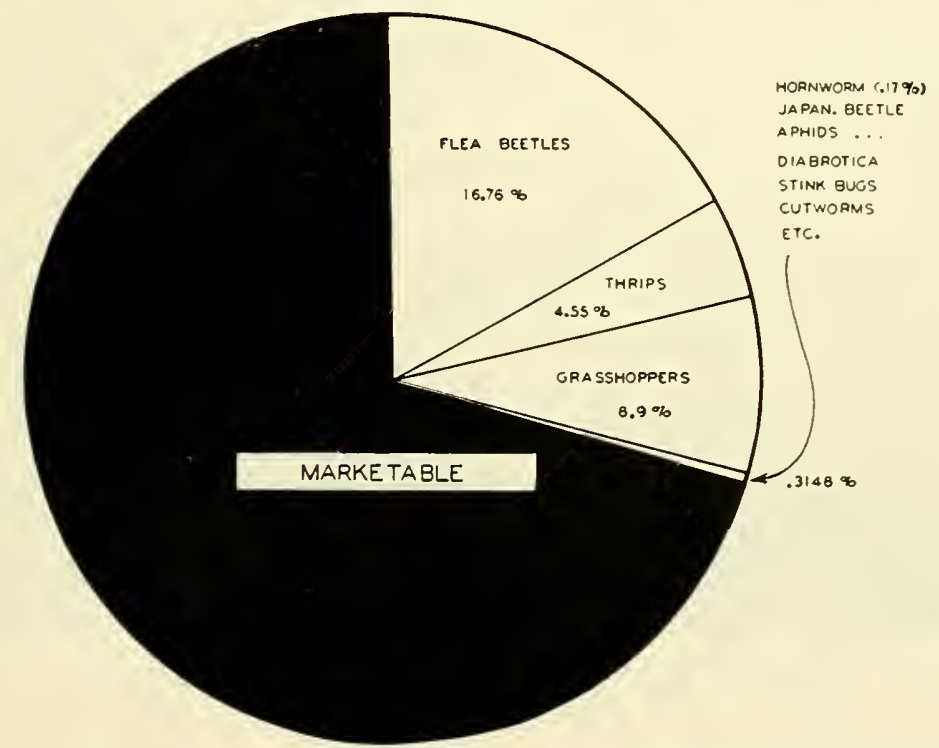

FIGURE 5. Estimated average damage by some of the principal insect pests of sun-grown tobacco, as determined by a series of field examinations made immediately before harvest in the Connecticut River Valley, 1940. 
1940 than for a number of years preceding. In general, the pests appeared late and some of the usual pests were not present in any appreciable numbers. Figure 5 is a graphical representation of the estimated average damage to tobacco by these various insects.

The Japanese Beetle, Popillia japonica Newman, again was observed in large numbers feeding on tobacco in a field of Havana Seed in tobacco in Manchester, Conn. Mowing of an adjoining hay field containing much jointweed, Polygonum pennsylvanicum L., a preferred natural host, apparently was the cause of the migration of the beetle to tobacco. As in 1939, injury was confined to the tops of the plants, and while occasionally severe, was very moderate considering the large numbers of beetles present.

The eastern field wireworm Limonius agonus Say, did less damage than usual, probably because of the delayed setting period and the dryness of the season afterward. Damage by the seed corn maggot, Hylemya cilicrura Rond., was not reported or observed, nor was there any by crane fly larvae or leatherjackets, which in this region usually are the larvae of Nephrotoma ferruginea F., Nephrotoma sodalis Loew, or Tipula georgiana Alex.

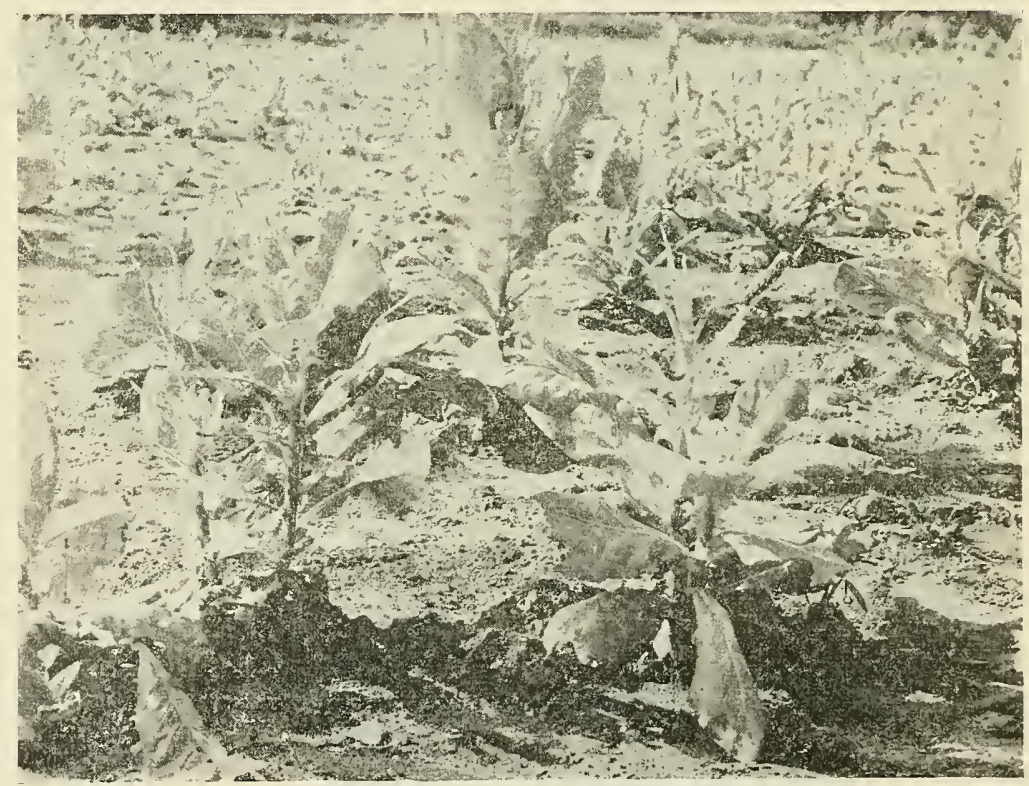

Figure 6. Suckers in field of sun-grown tobacco, showing larvae of Protoparce quinquemaculata (Haw.) feeding. Windsor, Connecticut, 1940.

The potato flea beetle, Epitrix cucumeris, Harr., and the tobacco thrips, Frankliniella fusca Hinds, were very scarce at the 
beginning of the season but became almost normally abundant for a brief period just before harvest. Injury by thrips was approximately the same as last year but injury by flea beetles was slightly more than one-third greater. Grasshoppers were rare until near harvest time when slightly more feeding was observed than in 1939. The injury in these fields was caused mainly by the red-legged grasshopper, Melanoplus femur-rubrum De G., rarely by the Carolina grasshopper, Dissosteira carolina L. Cutworms in seedbeds were not reported and only one case of injury by this insect to the growing plants was observed.

No specimens of the tobacco budworm, Heliothis virescens $\mathrm{F}$., were observed. A few light infestations of the tobacco hornworm, Protoparce quinquemaculata $\mathrm{Haw}$., were observed on sun-grown tobacco before harvest and several were found on the later suckers (Figure 6). While unlikely, it is possible for these worms to overwinter in this region and to emerge as moths during succeeding years. Such infestations on suckers are, therefore, potential sources of damage to subsequent tobacco crops and the suckers should be carefully destroyed when they appear after harvest.

Other usual pests of tobacco in this region, not reported in 1940, include the tarnished plant bug, Lygus pratensis L., the garden springtail Bourletiella hortensis Fitch, and the stalk borer, Papaipema nitela Guen. The spined stink bug, Euschistus variolarius Beauv., the spotted cucumber beetle, Diabrotica duodecimpunctata F., and the potato aphid, Illinoia solanifolii Ashm., were found doing very slight damage on one occasion each. 


\section{APPENDIX}

Average Analyses of Materials Which May Be Used in Tobacco Fertilization. Compiled by Tobacco Substation in Windsor, Conn.

\begin{tabular}{|c|c|c|c|c|c|c|c|}
\hline \multirow[b]{2}{*}{ Name of materials } & \multicolumn{7}{|c|}{ Percentage of nutrients } \\
\hline & $\begin{array}{c}\text { Nitro- } \\
\text { gen } \\
\mathrm{N}\end{array}$ & $\begin{array}{c}\text { Phos- } \\
\text { phoric } \\
\text { acid } \\
\mathrm{P}_{2} \mathrm{O}_{5}\end{array}$ & $\begin{array}{l}\text { Potash } \\
\mathrm{K}_{2} \mathrm{O}\end{array}$ & $\begin{array}{l}\text { Cal- } \\
\text { cium } \\
\mathrm{CaO}\end{array}$ & $\begin{array}{l}\text { Mag- } \\
\text { nesia } \\
\text { MgO }\end{array}$ & $\begin{array}{l}\text { Sulfur } \\
\mathrm{SO}_{3}\end{array}$ & $\begin{array}{l}\text { Chlorine } \\
\mathrm{Cl}\end{array}$ \\
\hline $\begin{array}{l}\text { Cottonseed meal } \\
\text { Linseed meal } \\
\text { Soybean oil meal } \\
\text { Castor pomace } \\
\text { Dry ground fish }\end{array}$ & $\begin{array}{l}6.5 \\
6.0 \\
7.2 \\
5.5 \\
9.0\end{array}$ & $\begin{array}{l}3 \\
2 \\
1.6 \\
2 \\
7\end{array}$ & $\begin{array}{l}2 \\
1 \\
2.5 \\
1 \\
1.1\end{array}$ & $\begin{array}{r}3 \\
.6 \\
.6 \\
1.0 \\
8.6\end{array}$ & $\begin{array}{r}.7 \\
.8 \\
.6 \\
1.0 \\
.4\end{array}$ & $\begin{array}{r}.5 \\
.9 \\
.3 \\
4.6\end{array}$ & $\begin{array}{r}.04 \\
.07 \\
.03 \\
.45\end{array}$ \\
\hline $\begin{array}{l}\text { Corn gluten meal } \\
\text { Nitrate of soda (Chilean) } \\
\text { Nitrate of soda } \\
\text { (Synthetic American) } \\
\text { Nitrate of lime }\end{array}$ & $\begin{array}{l}6.0 \\
16 \\
16 \\
15\end{array}$ & $\begin{array}{l}1.3 \\
\cdots \\
\cdots \\
\cdots\end{array}$ & $\begin{array}{r}.6 \\
\ldots .\end{array}$ & 27.1 & $\begin{array}{l}.6 \\
.2 \\
.06 \\
2.5\end{array}$ & $\begin{array}{l}.2 \\
.2 \\
.05\end{array}$ & $\begin{array}{l}.6 \\
.2 \\
.17\end{array}$ \\
\hline $\begin{array}{l}\text { Cal-nitro } \\
\text { Cal-nitro (Dolomitic) } \\
\text { Nitrate of soda-potash } \\
\text { Nitrate of potash } \\
\text { Urea (Uramon) }\end{array}$ & $\begin{array}{l}16 \\
20.5 \\
14 \\
13 \\
42\end{array}$ & $\begin{array}{l}\cdots \\
\cdots \\
\cdots \\
\cdots\end{array}$ & $\begin{array}{l}\cdots \\
14 \\
44 \\
\cdots\end{array}$ & $\begin{array}{r}27 . \\
11.4 \\
.2 \\
.6\end{array}$ & $\begin{array}{l}.13 \\
7.4 \\
.16 \\
.4\end{array}$ & $\begin{array}{l}\cdots \\
.07 \\
.7\end{array}$ & $\begin{array}{r}\text { None } \\
.5 \\
1.1\end{array}$ \\
\hline $\begin{array}{l}\text { Urea (European) } \\
\text { Sulfate of ammonia } \\
\text { Ammophos A } \\
\text { Ammophos B } \\
\text { Hoof and horn meal }\end{array}$ & $\begin{array}{l}46 \\
20.5 \\
11 \\
16.5 \\
15\end{array}$ & $\begin{array}{l}\cdots \\
48 \\
20 \\
\cdots\end{array}$ & $\begin{array}{l}\cdots \\
\cdots \\
\cdots \\
\cdots\end{array}$ & $\begin{array}{r}\text { None } \\
1.8 \\
.4 \\
2.7\end{array}$ & $\begin{array}{c}\text { None } \\
.6 \\
.3 \\
.2\end{array}$ & $\begin{array}{r}58.7 \\
6.5 \\
38.5 \\
1.8\end{array}$ & $\begin{array}{c}.8 \\
\text { Trace } \\
\ldots \ldots \ldots\end{array}$ \\
\hline $\begin{array}{l}\text { Peruvian guano } \\
\text { Fresh stable manure, cow } \\
\text { "“ horse } \\
\text { Precipitated bone } \\
\text { Bone meal (Raw) }\end{array}$ & $\begin{array}{r}16 \\
.5 \\
.6 \\
3.5\end{array}$ & $\begin{array}{r}10.8 \\
.3 \\
40 \\
24\end{array}$ & $\begin{array}{r}2.7 \\
.5 \\
.4 \\
\cdots \\
\cdots\end{array}$ & $\begin{array}{l}11 . \\
.2 \\
30 \\
31\end{array}$ & $\begin{array}{l}.9 \\
.1 \\
.2 \\
.5 \\
.8\end{array}$ & $\begin{array}{r}3.6 \\
.1 \\
.1 \\
3.4 \\
.6\end{array}$ & $\begin{array}{r}1.9 \\
.1 \\
.1 \\
1.2 \\
.2\end{array}$ \\
\hline $\begin{array}{l}\text { Bone meal (Steamed) } \\
\text { Superphosphate } \\
\text { Cottonhull ash } \\
\text { Sulfate of potash (European) } \\
\text { " " (American }\end{array}$ & $\begin{array}{l}2.5 \\
\cdots \\
\cdots \\
\cdots \\
\cdots\end{array}$ & $\begin{array}{c}23 \\
20 \\
3 \\
\cdots \\
\cdots\end{array}$ & $\begin{array}{l}25-40 \\
48 \\
52\end{array}$ & $\begin{array}{l}33 \\
27 \\
11 \\
.5\end{array}$ & $\begin{array}{l}.4 \\
5^{.5} \\
1.0 \\
\cdots\end{array}$ & $\begin{array}{r}29.3 \\
2.5 \\
43.5 \\
47.0\end{array}$ & 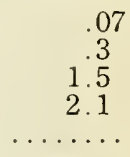 \\
\hline $\begin{array}{l}\text { Sulfate of potash-magnesia } \\
\text { Carbonate of potash } \\
\text { Tobacco stems, ground } \\
\text { “" long } \\
\text { Tobacco stalks, ground }\end{array}$ & $\begin{array}{l}\cdots \\
1.3 \\
2.5 \\
3.4\end{array}$ & $\begin{array}{l}7 . \\
.7 \\
.7 \\
.8\end{array}$ & $\begin{array}{l}25 \\
64 \\
5-7 \\
6.0 \\
4.6\end{array}$ & $\begin{array}{r}2.0 \\
2 \\
5-10 \\
5\end{array}$ & $\begin{array}{r}11.0 \\
\text { None } \\
.6 \\
.6 \\
\ldots .\end{array}$ & $\begin{array}{r}46.0 \\
.6 \\
1.0 \\
1.2 \\
\cdots\end{array}$ & $\begin{array}{l}2.0 \\
.4 \\
1.2 \\
\cdots \cdots \\
\cdots\end{array}$ \\
\hline $\begin{array}{l}\text { Limestone (High calcium) } \\
\text { " (High magnesia) } \\
\text { Hydrated lime (High calcium) } \\
\text { " ( } \text { magnesia) }\end{array}$ & & & & $\begin{array}{l}44 \\
30 \\
65 \\
45\end{array}$ & $\begin{array}{r}5.6 \\
20 \\
1.5 \\
27.0\end{array}$ & .1 & $\begin{array}{l}\text { Trace } \\
\ldots \ldots \ldots \\
\ldots \ldots \ldots \\
\ldots \ldots \ldots\end{array}$ \\
\hline $\begin{array}{l}\text { Kieserite, (magnesium sulfate, } \\
\text { calcined) } \\
\text { Emjeo, (magnesium sulfate) } \\
\text { Landplaster (Gypsum) } \\
\text { Wood ashes }\end{array}$ & & & $\begin{array}{l}\cdots \\
\cdots \\
4-6\end{array}$ & $\begin{array}{r}.6 \\
3.0 \\
32.0 \\
28-36\end{array}$ & $\begin{array}{r}32.0 \\
30.0 \\
.7 \\
3.5\end{array}$ & $\begin{array}{r}64.0 \\
66.0 \\
43.0 \\
1.0\end{array}$ & $\begin{array}{r}.02 \\
\text { Trace- } \\
.5\end{array}$ \\
\hline
\end{tabular}




University of Connecticut Libraries 
